SUSAN M. COLLINS

Brookings Institution and Georgetown University

B A R R Y P. BOSWOR TH

Brookings Institution

\title{
Economic Growth in East Asia: Accumulation versus Assimilation
}

THE IMPRESSIVE economic performance of many Asian economies during the past three decades is now an old story. The growth of per capita GDP averaged over 4 percent in China and the major East Asian economies (Indonesia, Korea, Malaysia, the Philippines, Singapore, Taiwan, and Thailand) between 1960 and 1994, compared with less than 2 percent in other developing economies and 2.6 percent among the industrial countries. ${ }^{1}$ East Asia stands out as the only region where living standards are catching up to those in industrial countries, while other parts of the developing world seem to be struggling to either tread water or fall further and further behind (see table 1).

The exemplary performance of many East Asian economies has been the basis for a large and varied literature, much of which explores reasons for the persistently high growth and draws lessons for other countries that would like to follow suit. A surprising aspect of this literature is the lack of agreement on fundamental aspects of the performance record that analysts seek to explain. Is the basis for East

Aslihan Yildiz assisted in the preparation of the paper, and a special debt is owed to $\mathrm{Yu}$-Chin Chen, who assisted with the construction of the data for the growth accounts. The views expressed are those of the authors and should not be interpreted as representative of the staff or trustees of the Brookings Institution.

1. East Asia, as a region, is defined to exclude China and Japan. Our somewhat unconventional group of East Asian economies is based on the availability of data to construct the growth accounts. We include all but two (China and Hong Kong) of the eight economies that were the focus of the World Bank study The East Asian Miracle (World Bank, 1993a) and add the Philippines. We include Japan with the industrial economies. 
Table 1. Basic Indicators of Economic Growth, by Region and Countrya Units as indicated

\begin{tabular}{|c|c|c|c|c|c|c|}
\hline \multirow{2}{*}{$\begin{array}{l}\text { Region and } \\
\text { country }\end{array}$} & \multirow{2}{*}{$\begin{array}{c}\text { Population } \\
1990^{\mathrm{b}}\end{array}$} & \multicolumn{2}{|c|}{$\begin{array}{c}\text { Per capita } \\
\text { income }^{\mathrm{c}}\end{array}$} & \multicolumn{3}{|c|}{ Growth rates, $1960-94^{\mathrm{d}}$} \\
\hline & & 1960 & 1990 & $G D P$ & Population & Labor force \\
\hline China & 1,134 & 0.6 & 1.3 & 6.8 & 1.8 & 2.3 \\
\hline East Asia & 380 & 0.9 & 3.6 & 6.8 & 2.2 & 2.5 \\
\hline Indonesia & 178 & 0.6 & 2.0 & 5.7 & 2.1 & 2.2 \\
\hline Korea & 43 & 0.9 & 6.7 & 8.5 & 1.7 & 2.6 \\
\hline Malaysia & 18 & 1.4 & 5.1 & 7.0 & 2.6 & 3.0 \\
\hline Philippines & 61 & 1.1 & 1.8 & 3.8 & 2.7 & 2.5 \\
\hline Singapore & 3 & 1.6 & 11.7 & 8.3 & 1.7 & 2.7 \\
\hline Thailand & 56 & 0.9 & 3.6 & 7.7 & 2.4 & 2.5 \\
\hline Taiwan & 20 & 1.3 & 8.1 & 8.7 & 2.1 & 2.7 \\
\hline South Asia & 1,130 & 0.8 & 1.1 & 4.2 & 2.3 & 1.9 \\
\hline Africa & 432 & 0.6 & 0.7 & 2.9 & 2.8 & 2.6 \\
\hline Middle East & 175 & 1.9 & 3.0 & 4.5 & 2.9 & 2.9 \\
\hline Latin America & 421 & 2.4 & 4.1 & 4.2 & 2.4 & 2.7 \\
\hline Industrial countries & 853 & 6.4 & 14.9 & 3.5 & 0.9 & 1.1 \\
\hline
\end{tabular}

Source: Population and GDP are the authors' calculations based on data from the World Bank's CD-ROM World Data 1995 (hereafter referred to by its title alone). Per capita income is calculated using data from the Penn-World Tables, mark 5.6 (accessed via the worldwide web page of the National Bureau of Economic Research). Labor force numbers are from unpublished data provided by the International Labour Organisation.

a. Computed using the eighty-eight country sample. Regional averages are calculated by weighting each country by its average GDP over 1960-94, as measured in 1985 dollars

b. Millions.

c. Thousands of 1985 dollars.

d. Annual percentage rate.

Asian growth the maintenance of high rates of physical and human capital accumulation over a number of decades - a willingness to make the sacrifices of current consumption necessary to invest for the future? Or has the key been the less costly approach of adopting existing technologies from more advanced economies, which may be associated with increased capital accumulation along the way?

Establishing which of these characterizations is correct is a crucial first step in extracting appropriate lessons from East Asian growth experiences and is a primary motivation for this paper. If the accumulation view is correct, these experiences reinforce the lesson that to improve living standards requires investment, paid for in large part through forgone current consumption. The alternative assessment, which Paul Romer has referred to as narrowing the "idea gap," implies a much more optimistic message. ${ }^{2}$ No opportunity cost need be incurred to

2. Romer (1993). 
incorporate ideas. Instead, they could be transmitted to the mutual benefit of suppliers and recipients. Deciphering East Asia's rapid growth would thus hold forth the promise of a much less steep road to prosperity.

A long list of authors implicitly or explicitly highlights productivity growth as the key to East Asian success. One strand of literature has engaged in a debate over the role of government policies (particularly microeconomic) in achieving productivity increases. In the early incarnation of this debate, some pointed to high-growth Asian economies as proof that "'market friendly" approaches, including the maintenance of an open trading regime, promoted increased efficiency. ${ }^{3}$ Others characterized government strategies in the region as targeted intervention, not laissez-faire, arguing that the experiences showed how "getting prices wrong" and picking winners were the road to catching up with industrialized nations. ${ }^{4}$ Thus the same group of countries became poster children for conflicting policy advice. Views in this debate have moved somewhat closer over time. In particular, there is now broad recognition that the high-growth Asian economies exhibit a range of government strategies, from extreme laissez-faire to extensive intervention in some sectors. A growing number of analysts have also concluded that some interventions were beneficial. ${ }^{5}$ However, considerable disagreement remains over the importance and transferability of active intervention. ${ }^{6}$ This debate still centers on the role of the public sector versus the private sector in generating productivity growth.

A second strand of literature stems from dissatisfaction with the ability of traditional growth models to explain observed features of economic growth. ${ }^{7}$ The result has been an exploration of alternative frameworks, known collectively as models of endogenous growth. Some of the underlying ideas can be found in the development literature of the 1950s and 1960s, but the associated explosion of attention to how rapid economic growth may be spurred by increases in efficiency is certainly new. In these models, while productivity gains may induce

3. See World Bank (1993a) and, more recently, Krueger (1995).

4. See Amsden (1989, 1991, 1994), Wade (1990), and Fishlow and others (1994).

5. See for example, World Bank (1993a), Krugman (1992), and Stiglitz (1996).

6. See, in particular, the debate that followed the publication of World Bank (1993a); for example, Singh (1994), Page (1994), Ito (1994), and Ito and Krueger (1995).

7. See, for example, Barro and Sala-i-Martin (1995), Grossman and Helpman (1991, 1994), Lucas (1988), Pack (1994), and Romer (1986, 1994). 
capital accumulation so that the two are observed to grow hand in hand, it is the productivity gains, not capital formation per se, that is the fundamental cause of growth. ${ }^{8}$

The following quotations imply an acceptance of the view that rapid economic growth, such as that seen in East Asia, can largely be explained by successfully catching up with technology: “The optimistic view of the potential for development suggested by idea gaps is consistent with the experience of a few, very rapidly growing economies. In fact, a rapidly closing idea gap offers the best way to explain these cases of dramatic success." And, "the source of growth in a few Asian economies was their ability to extract relevant technological knowledge from industrial economies and utilize it productively within the domestic economy.",

This literature has also looked for policy lessons, and many authors have concluded that openness to trade, imports of capital goods, direct foreign investment, financial development, and macroeconomic stability can help countries to grow by closing technology gaps. These claims are based on a combination of cross-country growth regressions and evidence from industry- and firm-level studies. ${ }^{10}$

Not so fast, argue a growing number of empirical studies that find little or no evidence that East Asia's rapid growth has been associated with rapid productivity growth or closing the knowledge or technology gap. The best known of these studies are Alwyn Young's growth accounting papers examining the composition of growth in Korea, Taiwan, Hong Kong, and Singapore. Jong-Il Kim and Lawrence Lau, using regression analysis to estimate underlying production functions, are unable to reject the hypothesis of no technical progress in the same four economies. ${ }^{11}$ If these studies are correct, and efficiency gains are not lead actors in the Asian success stories, then debates over the roles of government and the private sector in raising productivity, while of interest in their own right, cannot hope to uncover the lessons from Asian experience.

This paper revisits the issue of the sources of East Asia's rapid

8. See Barro and Sala-i-Martin (1992), Romer (1990), King and Levine (1994).

9. Romer (1993, p. 547); Pack (1992, p. 299).

10. See, for example, Bell and Pavitt (1992), Pack (1992), Romer (1993), and Fagerberg (1994).

11. Young (1991, 1994, 1995); Kim and Lau (1994). 
growth in output. The empirical framework is provided by a set of growth accounts that decompose the growth in output per worker from 1960 to 1994 into the contributions from the accumulation of physical and human capital and a residual measure of the change in total factor productivity (TFP). Our methodology is simpler, and therefore more transparent, than many of the other growth accounting studies in the literature. Furthermore, we apply a common methodology to eightyeight developing and industrial countries, including East Asian economies as well as countries from other regions at all levels of development. We focus on seven East Asian economies: Indonesia, Korea, Malaysia, the Philippines, Singapore, Taiwan, and Thailand. China is included in the sample but is treated separately because of concerns about the data. Japan is included among the industrial countries, not East Asia.

Growth accounting has recently been subject to criticism because it cannot identify the fundamental causes of growth. However, this is not its objective. It provides a consistent decomposition of growth among its proximate sources, which we believe is very informative. This approach also avoids some of the problems associated with cross-country regression analyses. In particular, it has been widely recognized that because such studies suffer from simultaneity, multicolinearity, and limited degrees of freedom, their results should be interpreted with caution. ${ }^{12}$ Note also that growth accounting does not require taking a stand on the appropriate underlying model of growth. There is no need to choose between a neoclassical framework, in which technology is identical across countries and technical progress is exogenously determined, and the many alternative frameworks in which technology may differ across countries and the accumulation of knowledge is an endogenous process.

The central result of our empirical analysis reinforces those studies that have concluded that TFP growth played a surprisingly small role in East Asia's success. The main lessons of this success come not from identifying which policies best promote TFP growth, but how countries can achieve and sustain high rates of saving and investment. The saving and investment record in East Asia has been impressive, and govern-

12. See Mankiw (1995) for one exposition of the difficulties with the empirical analysis. 
ment policies may well have been a key contributor to this accomplishment. Further, we emphasize that East Asia has avoided the fate of other regions where large negative productivity shocks sharply lowered the level of TFP. With the exception of the Philippines, improvements in efficiency consistently made positive (if small) contributions to growth in the region.

Finding little TFP growth among these countries is not new. Indeed, our results are similar to Young's in this regard. The main contributions of our work fall into three areas. The first is its extensive coverageparticularly within East Asia. Other studies typically focus on two countries (Korea and Taiwan) and two tiny city-states (Hong Kong and Singapore) whose experience may be of limited relevance for larger economies. In its inclusion of Indonesia, Malaysia, the Philippines, and Thailand, our analysis represents a significant expansion of information about developments in the region. Our large sample enables us to make comparisons across countries and time periods such that different experiences cannot be attributed to methodological inconsistencies. We are able to study the robustness of Young's conclusions which, because they are based on a very detailed decomposition, cannot be contrasted directly with those for other countries. We also examine the relationship between factor accumulation and productivity growth in these economies.

Second, our analysis clarifies why some previous studies have underemphasized the importance of capital accumulation in East Asia. We show that using investment to proxy physical or human capital accumulation can be very misleading. These proxies are surprisingly uncorrelated with changes in capital stocks. Furthermore, they lead to severe underestimates of the role of physical capital in explaining high Asian growth. We also examine the ways of measuring human capital accumulation. We argue that using years of schooling directly is problematic. Because of the way in which it treats those with no formal education, this method overstates growth in human capital for countries with low initial levels of education relative to our labor quality index, which weights labor on the basis of returns to schooling. This alternative implies a larger, though still modest, contribution to growth from increased schooling in East Asia relative to other regions.

Third, we use the decomposition of growth into factor accumulation and productivity gains to explore the channels through which variations 
in initial conditions, the external environment, and some aspects of government policy have affected the growth process. In some cases the roles of various policies can be evaluated by examining the extent to which they are correlated with changes in factor accumulation as against gains in the efficiency with which the factors are used.

In the sections that follow, we explain the construction of the accounts and discuss the results as they bear on the East Asian experience. We use the resulting data to explore the context in which East Asian economic growth has been distinctive. Is there, as emphasized by the new growth literature, a positive correlation between capital accumulation and factor productivity gains and, if so, was it important for East Asia? Proceeding from our emphasis on the dominant role of capital accumulation, we examine a further issue raised by Paul Krugman (based on Young's analysis): whether or not East Asian growth must inevitably slow down. ${ }^{13} \mathrm{We}$ suggest that there is some evidence that these economies are evolving toward a greater emphasis on TFP gains and that future growth can be sustained.

\section{Construction of the Accounts}

Growth accounts make it possible to decompose the change in output into the contributions of factor accumulation and a residual measure of gains in the efficiency with which the factors are used. Most previous studies have been restricted to a select few countries for which the researcher was able to obtain the required information from national sources. ${ }^{14}$ In recent years the situation has been changed by the development of several large international data sets. We use these data sets to construct growth accounts that, while simpler than those available from other sources, cover a large number of economies over an extended period. Thus they augment the other studies by employing a standardized and transparent methodology to compare the growth experience of a large number of countries. Comparisons can be made between the growth experience in East Asia and in the industrial coun-

13. Krugman (1994).

14. Three of the most detailed recent examples are Elias (1992), covering seven Latin American countries; Hofman (1993), comparing six Latin American countries with three in Asia; and Young (1995), for four newly industrializing economies in Asia. 
tries and developing economies in other regions, without concern for differences in methodology.

We construct indexes of real output, the capital stock, and a measure of the education-adjusted work force for eighty-eight countries over the period 1960-94. The choice of countries is limited primarily by the availability of national accounts data and measures of educational attainment, but the result provides very good coverage of the major regions: East Asia (eight countries), South Asia (five), sub-Saharan Africa (twenty-one), the Middle East and North Africa (nine), Latin America (twenty-two), and the industrial countries (twenty-three).$^{15}$ In addition, we use an updated version of the Penn-World Tables (PWT) to obtain relative levels of output and capital per worker in common international prices (see below).

The neoclassical analysis of economic growth starts with the assumption of a stable underlying relationship between output $(Q)$, the inputs capital $(K)$ and labor $(L)$, and technology $(A)$ :

$$
Q_{t}=F\left(K_{t}, \hat{L}, A_{t}\right) \text {. }
$$

$L$ is used to denote a skill-adjusted measure of the labor input, such that

$$
\dot{L}=H L,
$$

where $H$ is an index of labor quality. In concept, the growth accounts can be constructed to yield estimates of total factor productivity that are independent of the parameters or functional form of the above production process. It is only necessary to assume a degree of competition sufficient to ensure that the earnings of the factors are proportionate to their factor productivities. The shares of income paid to the factors can then be used to measure their relative importance in the production process. That is, an index of growth in total factor productivity, denoted by $a(t)$, can be defined as the growth rate of output, $q(t)$, less the share-weighted growth of the factor inputs, $k(t)$ and $l(t)$ :

$$
a(t)=q(t)-s_{k} k(t)-s_{l} l(t) .
$$

As discussed below, we are compelled to use fixed weights-an assumption that is only consistent with a more limited set of production

15. A complete list is given in appendix $\mathbf{A}$. 
functions-in the construction of the indexes. Furthermore, any deviation from constant returns to scale is allocated to the residual of total factor productivity.

\section{Output Growth}

The basic output measure is gross domestic product in national prices of 1987, from the World Bank's CD-ROM World Data 1995. Because of data revisions and some reporting errors, we substitute measures from the International Monetary Fund (IMF) and the Organisation for Economic Co-operation and Development (OECD) in a few cases. An alternative measure of GDP in international prices with a base year of 1985 is available in the Penn-World Tables, mark 5.6. ${ }^{16}$ While the PWT measure starts from the same national accounts data as the World Bank, it is converted to standard international prices by constructing indexes in national prices at the level of the three main components of real GDP (private consumption, government consumption, and investment) and forming a new aggregate using international price weights. ${ }^{17}$

The composition of output measured in international prices can deviate from that shown by the standard national accounts, which are measured in national prices. Most of these differences can be traced to wide variations across countries in the price of labor in nontraded products, but they also reflect the influence of various restrictions on external trade that prevent an equalization of the domestic and foreign prices of tradables. In general, for high-income countries the conversion to international prices raises the share of output devoted to investment (capital and skill intensive) and lowers the share devoted to government consumption (labor intensive). The opposite is true for poor countries.

The measurement of output in common international prices is of great value for comparing levels of income across countries. However, the international and the national price measures produce very similar estimates of output change. ${ }^{18}$ Over the period 1960-90, the correlation coefficient between the two measures exceeds 0.95 for our sample. The difference in the average annual growth rate exceeds one percentage

16. Accessed on the worldwide web page of the National Bureau of Economic Research.

17. For further discussion, see Summers and Heston (1991).

18. The differences in weights will have large effects on the growth in the aggregate only if the growth rates of the components are widely divergent. 
point in only six countries; and in one such case, China, the disparity reflects a special revision of the national source data by the authors of the PWT. ${ }^{19}$ In this paper we report output growth in terms of national prices because our data for these are more up to date (through 1994) and capture some important data revisions.

\section{Physical Capital}

The measure of the capital stock is based on a perpetual inventory estimation with a common geometric depreciation rate of 0.04 . Estimates of the capital stock are normally considered unreliable due to lack of information about the initial capital stock and the rate of depreciation. However, the researchers who developed the World Bank data set devoted substantial effort to incorporating the results of previous studies of individual or small groups of countries, and they obtained investment data extending as far back as $1950 .{ }^{20}$ The long time series on investment is significant because it reduces the importance of the assumption about the initial stock. For the East Asian economies in particular, where subsequent investment rates have been very high, any error in the estimate of the capital stock for the 1950 s would be a very small portion of the stock available in the 1980s and 1990s.

An alternative approach, reflecting skepticism about estimating the capital stock, uses the gross investment rate as a proxy for the change in the capital stock. The change in the capital stock is given by

$$
\Delta K=I-d K
$$

where $I$ is investment and $d$ is a measure of the geometric rate of depreciation. Dividing through by $K$ and assuming a steady-state constant value $(\gamma)$ for the inverse of the capital-to-output ratio allows the rate of change of capital $(k)$ to be measured by the investment rate $(i=I / Q)$ :

19. The six countries with large differences are China, Jordan, Mali, Myanmar, Nigeria, and Rwanda. In the case of China, the PWT reflect a special adjustment to the underlying national accounts over the period 1980-93 that reduced the growth rate of investment by 40 percent and that of consumption by 30 percent. In the other cases, it appears that the World Bank measures of GDP had been revised since the data were gathered for the PWT.

20. Nehru and Dhareshwar (1993). We extend the estimates through 1994 by using data from the World Bank's CD-ROM World Data 1995. 


$$
k=i \gamma-d .
$$

Most previous cross-national growth studies have relied on the investment rate to measure capital accumulation. The approach is typically justified either by the assumption of a steady state or by a linearization around a steady state. ${ }^{21}$

The choice between using a direct estimate of the capital stock and its steady-state investment equivalent is critical to deciphering the differences among the various studies that have sought to explain East Asian growth. The growth experience of many developing countries over the past three decades has been very far from the conditions of a steady state, and the capital-to-output ratio has been far from constant. As a result the investment rate is a very poor proxy for the rate of capital accumulation. In fact, in our sample of eighty-eight countries there is no significant correlation between the rate of change in the capital stock and the mean investment rate, even over a period as long as thirty-four years (see figure 1 and the associated table 2). ${ }^{22}$

The newly industrializing economies of Asia all have extraordinarily high rates of growth of the capital stock, but they are less distinctive in terms of the share of output devoted to investment. The combination of an elevated investment share and a rapid growth of output has yielded a very high rate of capital accumulation for these economies, but there are other countries with high investment shares that have had less output growth.

It is also possible to use the PWT data to construct estimates of the capital stock in international prices. However, because the growth in investment spending is the same in national and international prices, the choice between the two measures affects only the level of the capital input. ${ }^{23}$

21. See Mankiw, Romer, and Weil (1992) and the studies referenced in Levine and Renelt (1992).

22. Under the assumption of linear deviations from a steady state (Mankiw, Romer, and Weil, 1992), capital accumulation should depend on initial conditions as well as on the investment rate. To explore this relationship, we add average investment rates to a regression equation explaining variation in our measure of the contribution of increases in physical capital per worker. The international price investment share has a coefficient of only 0.03 and increases the regression's explanatory power $\left(\bar{R}^{2}\right)$ by only 0.04 . The national price investment share adds no explanatory power. Thus we conclude that investment rates are very poor proxies for capital accumulation.

23. To construct an estimate of the capital stock in international prices, we adjust 
Figure 1. Capital Stock Growth and Average Investment Rates, by Country, 1960-94

Capital stock growth (annual percentage rate)

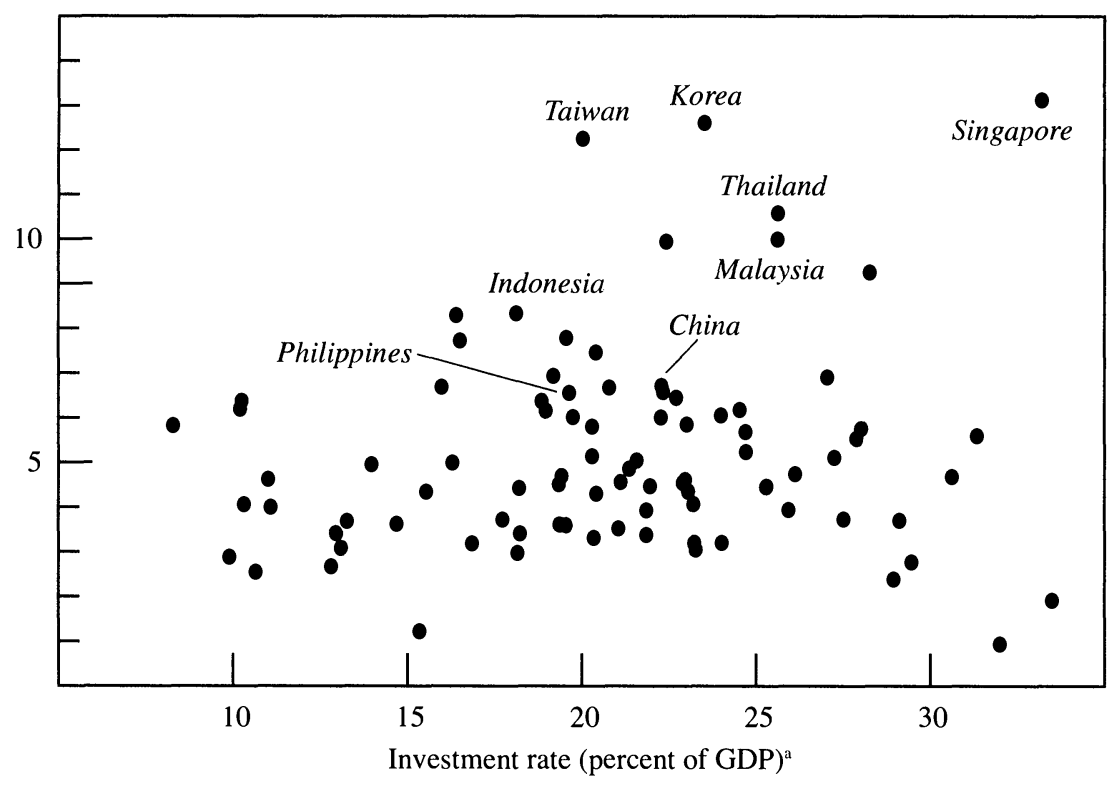

Source: See table 2 .

a. Measured in national prices.

\section{Labor Inputs}

The measure of the quantity of labor is actual employment for the industrial countries and for the other countries, unpublished estimates of the economically active (labor force) population from the International Labour Organisation (ILO). For many countries, data on the economically active population are available only every five or ten years, from population surveys or censuses. The ILO has used information on age-specific labor force participation rates and more frequent population estimates to develop consistent estimates of the labor force at five-year intervals extending over the period 1960-90. Those participation rates are then interpolated and applied to annual estimates of the total population.

the initial capital-to-output ratio in line with the ratio of the investment rate in national prices and international prices in the 1960s. 
Table 2. Capital Stock Growth and Average Investment Rates, by Region and Country, 1960-94a

Units as indicated

\begin{tabular}{lccc}
\hline & & \multicolumn{2}{c}{ Investment rate $^{\mathrm{c}}$} \\
\cline { 3 - 4 } Region and country & $\begin{array}{c}\text { Capital } \\
\text { stock }\end{array}$ & $\begin{array}{c}\text { National } \\
\text { grices }\end{array}$ & $\begin{array}{c}\text { International } \\
\text { prices }\end{array}$ \\
\hline China & 6.7 & 22.3 & 20.5 \\
East Asia & 9.9 & 21.1 & 18.6 \\
Indonesia & 8.3 & 18.1 & 17.1 \\
Korea & 12.6 & 23.5 & 23.7 \\
Malaysia & 10.0 & 25.6 & 23.5 \\
Philippines & 6.0 & 19.8 & 15.3 \\
Singapore & 13.1 & 33.2 & 31.2 \\
Thailand & 10.6 & 25.6 & 18.1 \\
Taiwan & 12.2 & 20.0 & 21.9 \\
South Asia & 5.2 & 18.9 & 11.3 \\
Africa & 4.8 & 19.0 & 9.5 \\
Middle East & 7.1 & 19.0 & 12.6 \\
Latin America & 5.4 & 21.4 & 16.9 \\
Industrial countries & 4.5 & 20.8 & 24.5 \\
\hline
\end{tabular}

Source: Capital stock growth is calculated using data from Nehru and Dhareshwar (1993). Investment rate data are from World Data 1995 (national prices) and the Penn-World Tables, mark 5.6 (international prices).

a. Computed using the eighty-eight country sample. Regional averages are calculated by weighting each country by its average GDP over $1960-94$, as measured in 1985 dollars.

b. Annual percentage rate.

c. Percent of GDP.

The use of a labor force measure instead of the total population, as is more common in similar studies, makes little difference in the aggregate: over the period 1960-94, the two series have nearly identical growth rates at the level of the total sample ( 2.1 for the labor force and 2.0 percent for the total population), and the cross-country correlation of the change is 0.82 . It does makes a difference, however, at the level of individual countries; and it is important for evaluating the sources of growth in some of the East Asian economies (see the last two columns of table 1). The growth of the labor force exceeds that of the population in China and East Asia-with particularly large differences in Korea, Singapore, and Taiwan. Rising labor force participation is also evident in the industrial countries, but the opposite is true for the low-income, high-population growth economies of South Asia and sub-Saharan Africa. Thus using the labor force to measure growth in the labor input lowers the amount of growth attributed to TFP for the faster-growing economies and reduces its variance across countries. 


\section{Human Capital}

Measures of the labor force, in effect, treat all workers as if they were identical, but worker characteristics clearly influence marginal productivity. Some previous growth accounting studies of individual countries have incorporated detailed adjustments by labor force groupings, including education, age, and gender. ${ }^{24}$ We follow a simpler approach, adjusting only for the characteristic that has been found to be most important: education. The benefits of education are assumed to be embodied in workers, as explained below. ${ }^{25}$

Our analysis is based on the educational attainment data constructed by Robert Barro and Jong-Wha Lee. ${ }^{26}$ They use a combination of data sources to infer the percentage of each country's adult population (aged twenty-five and older) that had obtained a particular level of education for each year from 1960 to $1990 .{ }^{27}$ Census data provide direct measures of a country's stock of education in a particular year. However, such data are only available for selected years, particularly in developing countries. Therefore enrollment data are used to interpolate between census years and, along with data on literacy rates, to fill in missing cells. The result is an allocation of each country's population among seven schooling levels (ranging from no schooling-illiterate to completed postsecondary schooling) and an estimate of average years of schooling of the adult population constructed from the categorical data. Following their extrapolation procedures, we extend the data to 1994. Seven of the countries in our sample are not in the Barro-Lee data set. ${ }^{28}$ In these cases, we construct estimates using data on years of schooling compiled by Vikram Nehru, Eric Swanson, and Ashutosh Dubey, and the relationship between the two data sets for countries at comparable stages of development. ${ }^{29}$ Although we believe that the resulting indi-

24. For example, Denison (1967) and Young (1995).

25. Other formulations of the production function that treat the benefits of education separately from the workers, such as that of Mankiw, Romer, and Weil (1992), are reported in Bosworth, Collins, and Chen (1996).

26. Barro and Lee (1994a).

27. Thus we assume that the educational distribution of the population is representative of the educational distribution of the labor force.

28. These countries are China, Cote d'Ivoire, Egypt, Ethiopia, Madagascar, Morocco, and Nigeria.

29. Nehru, Swanson, and Dubey (1995). This alternative data set is based primarily on information about school enrollments. Surprisingly, although there is a very high 
Table 3. Educational Attainment and Labor Quality, by Region and Country ${ }^{\mathrm{a}}$ Units as indicated

\begin{tabular}{|c|c|c|c|c|}
\hline \multirow[b]{3}{*}{ Region and country } & \multirow{2}{*}{\multicolumn{2}{|c|}{ Average years of schooling }} & \multicolumn{2}{|c|}{ Growth rate, $1960-94^{\mathrm{b}}$} \\
\hline & & & \multirow{2}{*}{$\begin{array}{c}\text { Years of } \\
\text { schooling }\end{array}$} & \multirow{2}{*}{$\begin{array}{l}\text { Quality } \\
\text { index }^{\circ}\end{array}$} \\
\hline & 1960 & 1994 & & \\
\hline China & 1.7 & 5.3 & 3.5 & 0.6 \\
\hline East Asia & 2.7 & 7.2 & 3.0 & 0.9 \\
\hline Indonesia & 1.1 & 5.0 & 4.5 & 0.8 \\
\hline Korea & 3.2 & 9.7 & 3.3 & 1.2 \\
\hline Malaysia & 2.3 & 7.0 & 3.3 & 0.8 \\
\hline Philippines & 3.8 & 7.4 & 2.0 & 0.8 \\
\hline Singapore & 3.0 & 6.1 & 2.1 & 0.6 \\
\hline Thailand & 3.5 & 7.5 & 2.3 & 0.7 \\
\hline Taiwan & 3.2 & 8.2 & 2.8 & 1.0 \\
\hline South Asia & 1.3 & 3.4 & 2.8 & 0.5 \\
\hline Africa & 1.6 & 3.5 & $2: 4$ & 0.3 \\
\hline Middle East & 1.4 & 4.9 & 3.8 & 0.7 \\
\hline Latin America & 3.0 & 5.5 & 1.8 & 0.5 \\
\hline Industrial countries & 7.3 & 9.8 & 0.9 & 0.5 \\
\hline
\end{tabular}

Source: Authors' calculations as explained in text, based on data sets constructed by Barro and Lee (1994b) and Nehru, Swanson, and Dubey (1995).

a. Computed using the eighty-eight country sample. Regional averages are calculated by weighting each country by its average GDP over 1960-94, as measured in 1985 dollars.

b. Annual percentage rate.

c. The labor quality index $(H)$, as described in text, calculated using weights implied by a 7 percent return to each year of education.

cators represent the best available comprehensive educational data, there are a number of potentially serious measurement problems, and those problems may vary systematically with the level of development. ${ }^{30}$

Table 3 summarizes the average educational attainment for the populations of the East Asian countries anc the major regions worldwide. The first column reports average years of schooling in 1960. Countries in South Asia had the least educated population, followed by those in the Middle East and Africa. On average, East Asian countries had slightly less human capital (per person) than those in Latin America,

cross-country correlation between the two measures of the average level of schooling during the period 1960-85, the correlation vanishes in a comparison of changes over the period. There are also significant discrepancies between the two data sets for some industrial countries. As discussed further in Bosworth, Collins, and Chen (1996), we find the Barro-Lee data preferable.

30. See Behrman and Rosenzweig (1994) and Barro and Lee (1994a) for discussions of the problems with education and labor force data from developing countries. 
but educational attainment in both regions remained well below the average for industrial countries. As shown in the second column, by 1994 average educational levels in East Asia were second only to those in industrial countries and well above levels in all other nonindustrial regions. Of all the regions, East Asia experienced the greatest absolute increase in years of schooling between 1960 and 1994. However, as shown in the third column, East Asia (excluding China) is not the region with the most rapid percentage rate of increase in schooling. This distinction goes to the Middle East, where educational levels nearly tripled, but from an initially low base.

Prior empirical studies have frequently relied on enrollment rates as a proxy for changes in education. But the enrollment rate encounters a problem similar to that of the investment rate as a measure of physical capital accumulation: it only works in (or for linearizations around) the steady state. ${ }^{31}$ The enrollment rate that would be necessary to maintain constant average years of schooling in a country with an initially high stock would imply increasing years of schooling in a country with an initially low stock. ${ }^{32}$ Indeed, enrollment in 1965 and growth in years of schooling over the period 1965-85 are uncorrelated in the data sets of either Barro and Lee or Nehru, Swanson, and Dubey.

More recently, several studies have used the number of years of schooling as an explanatory variable. But, as Barro and Lee are careful to point out, the level of schooling at the beginning of a period should be interpreted as an initial condition, not a proxy for human capital accumulation. Indeed, the initial number of years of schooling has been found to be negatively correlated with the growth in years of schooling. Other studies have used the average years of schooling over the growth period, but this method also fails to measure the accumulation of human capital over the period. ${ }^{33}$

Many studies have even found it difficult to detect a significant relationship between the change in years of schooling and economic

31. This assumption, and its justification of linearization around the steady state, became very popular following the paper by Mankiw, Romer, and Weil (1992).

32. This point is also made in Benhabib and Spiegel (1994).

33. Benhabib and Spiegel (1994) justify use of the average level of schooling with an endogenous growth model in which productivity growth depends on the accumulated stock of human capital. 
growth.$^{34}$ Various explanations have been offered. Some emphasize the measurement problems in cross-country data on educational attainment. But it is also evident that years of schooling alone is a poor index of labor quality because it assigns workers with zero education a weight of zero and it implies disproportionate changes in labor quality for countries with low initial levels of schooling.

We have tried to follow Edward Denison and others in using estimates of the relative wage structure for workers with different years of schooling to construct weights for aggregating workers across educational levels. ${ }^{35}$ Our labor quality index,

$$
H=\sum W_{j} P_{j},
$$

weights the percentage of a country's population that has attained level $j$ of schooling $\left(P_{j}\right.$, where $j$ ranges from 1:no schooling to 7:beyond secondary completed) by our estimate of the return to level $j$ of schooling $\left(W_{j}\right)$. The weights are based on the observed relative earnings of different educational groups and reflect the assumption that percentage returns to schooling are constant across levels of schooling and countries.

A recent article by George Psacharopoulos provides a comprehensive survey of the empirical literature. ${ }^{36}$ The method most frequently used to estimate the return to education involves regressing log earnings on years of schooling, potential years of experience, potential experience squared, and a constant. The estimated coefficient on years of schooling can be interpreted as the average marginal return to an additional year of schooling. The assumption that the returns to schooling are constant across different schooling levels is consistent with David Card and Alan Krueger's recent findings for the United States. ${ }^{37}$ However, Psacharopoulos reports that the estimates for other countries frequently find larger returns for primary than for secondary or higher levels of education. ${ }^{38}$

34. Benhabib and Spiegel (1994), Pritchett (1995), Harrison (1996), and Judson (1996).

35. See Denison (1967).

36. Psacharopoulos (1994).

37. Card and Krueger (1996).

38. The earnings regression approach may overstate returns to schooling because it omits variables such as ability and family background. 
Table 4. Educational Attainment of Adult Population, by Region and Country, 1960 ${ }^{\mathrm{a}}$ Percent, except as indicated

\begin{tabular}{|c|c|c|c|c|c|c|c|c|}
\hline \multirow{2}{*}{$\begin{array}{l}\text { Region and } \\
\text { country }\end{array}$} & \multirow{2}{*}{$\begin{array}{c}\text { No } \\
\text { schooling }\end{array}$} & \multicolumn{2}{|c|}{$\begin{array}{c}\text { Completed } \\
\text { primary }\end{array}$} & \multicolumn{2}{|c|}{$\begin{array}{l}\text { Completed } \\
\text { secondary }\end{array}$} & \multicolumn{2}{|c|}{$\begin{array}{c}\text { Completed } \\
\text { higher }\end{array}$} & \multirow{2}{*}{$\begin{array}{l}\text { Average } \\
\text { return to } \\
\text { schooling }\end{array}$} \\
\hline & & No & Yes & No & Yes & No & Yes & \\
\hline East Asia & 56.6 & 16.3 & 17.7 & 4.2 & 3.0 & 0.7 & 1.4 & 10.7 \\
\hline Indonesia & 75.5 & 15.0 & 7.6 & 1.4 & 0.5 & 0.1 & 0.0 & 17.0 \\
\hline Korea & 56.9 & 3.4 & 26.2 & 5.1 & 5.8 & 0.7 & 1.9 & 10.6 \\
\hline Malaysia & 58.5 & 21.5 & 11.2 & 4.8 & 2.4 & 0.2 & 1.3 & 9.4 \\
\hline Philippines & 33.5 & 32.3 & 17.4 & 6.1 & 4.5 & 2.2 & 4.0 & 8.0 \\
\hline Singapore & 64.0 & 7.9 & 5.3 & 15.3 & 7.6 & 0.0 & 0.0 & 13.4 \\
\hline Thailand & 48.1 & 12.5 & 33.9 & 3.3 & 1.6 & 0.0 & 0.6 & 10.4 \\
\hline Taiwan & 47.0 & 24.9 & 13.9 & 5.8 & 4.2 & 2.1 & 2.2 & 6.0 \\
\hline South Asia & 76.7 & 14.5 & 5.2 & 2.1 & 1.3 & 0.0 & 0.1 & 7.2 \\
\hline Africa & 66.8 & 11.7 & 8.5 & 9.6 & 3.2 & 0.1 & 0.2 & 13.3 \\
\hline Middle East & 82.3 & 6.6 & 4.4 & 2.6 & 2.5 & 0.7 & 0.8 & 10.6 \\
\hline Latin America & 41.5 & 34.7 & 13.0 & 5.2 & 3.6 & 0.7 & 1.2 & 12.3 \\
\hline Industrial countries & 4.4 & 26.7 & 30.8 & 18.1 & 12.0 & 3.7 & 5.2 & 7.0 \\
\hline \multicolumn{9}{|l|}{ Addendum } \\
\hline 7 percent return & 100.0 & 125.0 & 150.0 & 187.0 & 225.0 & 262.0 & 300.0 & \\
\hline 12 percent return & 100.0 & 150.0 & 200.0 & 300.0 & 400.0 & 500.0 & 600.0 & \\
\hline
\end{tabular}

Source: Data on educational attainment are from the data sets constructed by Barro and Lee (1994b) and Nehru, Swanson, and Dubey (1995); and on returns to schooling, from Psacharopoulos (1994). Labor quality weights are the authors' calculations, as described in the text.

a. Data cover fifty-three of the eighty-eight sample countries. Regional averages are calculated by weighting each country by its average GDP over 1960-94, as measured in 1985 dollars.

b. The return to each additional year of schooling; see text for details.

The estimated average returns to schooling by region, drawn from data reported by Psacharopoulos, are summarized in table $4 .{ }^{39}$ Based on the range of regional estimates, we construct two indexes of labor quality, one using weights implied by a 7 percent return to schooling (a relatively low estimate) and the other using weights implied by a 12 percent return to schooling (a relatively high estimate). Both sets of weights assign a value of one hundred to individuals with no formal schooling. The weights implied by the 7 and 12 percent rates of return, respectively, at different levels of schooling are shown in table 4 . The table also shows the percentage distribution of the adult population

39. Estimates are available for fifty-three of the countries in our sample ( 60 percent), including all of the East Asian countries and eighteen of the twenty-two Latin American countries. The average return to an additional year of school in East Asia is 10.7 percent, slightly higher than the overall worldwide average of 10.2 percent. 
Table 5. Labor Quality Indexes, by Region and Country ${ }^{a}$ Index, except as indicated

\begin{tabular}{|c|c|c|c|c|c|c|}
\hline \multirow{3}{*}{$\begin{array}{l}\text { Region and } \\
\text { country }\end{array}$} & \multicolumn{3}{|c|}{7 percent return $^{\mathrm{b}}$} & \multicolumn{3}{|c|}{12 percent return ${ }^{\mathrm{b}}$} \\
\hline & \multicolumn{2}{|c|}{ Labor quality } & \multirow{2}{*}{$\begin{array}{c}\text { Growth } \\
\text { rate }^{\mathrm{c}}\end{array}$} & \multicolumn{2}{|c|}{ Labor quality } & \multirow{2}{*}{$\begin{array}{c}\text { Growth } \\
\text { rate }^{\mathrm{c}}\end{array}$} \\
\hline & 1960 & 1994 & & 1960 & 1994 & \\
\hline$\overline{\text { China }}$ & 109.9 & 135.3 & 0.6 & 120.5 & 183.9 & 1.3 \\
\hline East Asia & 123.2 & 166.1 & 0.9 & 151.8 & 252.9 & 1.5 \\
\hline Indonesia & 109.7 & 142.8 & 0.8 & 119.9 & 192.4 & 1.4 \\
\hline Korea & 130.6 & 197.4 & 1.2 & 167.8 & 331.5 & 2.0 \\
\hline Malaysia & 121.0 & 160.0 & 0.8 & 145.9 & 233.8 & 1.4 \\
\hline Philippines & 139.3 & 182.8 & 0.8 & 188.1 & 293.4 & 1.3 \\
\hline Singapore & 127.3 & 155.2 & 0.6 & 162.4 & 226.4 & 1.0 \\
\hline Thailand & 126.2 & 158.2 & 0.7 & 154.6 & 227.9 & 1.1 \\
\hline Taiwan & 131.1 & 182.1 & 1.0 & 169.5 & 294.2 & 1.6 \\
\hline South Asia & 109.9 & 129.9 & 0.5 & 121.2 & 169.5 & 1.0 \\
\hline Africa & 114.4 & 128.3 & 0.3 & 130.8 & 162.4 & 0.6 \\
\hline Middle East & 111.8 & 143.0 & 0.7 & 126.3 & 199.5 & 1.4 \\
\hline Latin America & 127.7 & 153.8 & 0.5 & 160.3 & 222.6 & 1.0 \\
\hline Industrial countries & 168.6 & 200.4 & 0.5 & 255.8 & 338.3 & 0.8 \\
\hline
\end{tabular}

across each of the seven educational levels in 1960 and 1994, by country and region. The two indexes, and their rates of growth over the sample period, are summarized in table 5. While growth accounting decompositions based on both indexes are presented and compared below, we treat the 7 percent return weights as our base. ${ }^{40}$

The growth rates of the labor quality indexes, assuming a 7 percent return, are reported in the fourth column of table 3 . In contrast to the findings of the raw years of schooling measure (third column), the labor quality measure shows that East Asia experienced the greatest increase in labor quality over the period 1960-94: a 0.9 percent annual rate of

40. There are two reasons for focusing on the decomposition under a 7 percent return. First, we believe that the likely biases due to omitted variables imply overestimates of returns to schooling among developing countries. Second, as discussed below, assuming a higher rate of return to schooling will result in a smaller residual, or estimate of total factor productivity, in East Asia. Since one of our main messages is that there is surprisingly little productivity growth for these countries, we want to ensure that this conclusion cannot be attributed to extreme underlying assumptions. 
growth. The quality index also sharply changes the picture of the distribution of education gains within the region. China and Indonesia, which begin with very low average years of schooling, appear to gain much less, and Korea jumps to the top of the ranking in terms of improvement. A similar phenomenon is evident in the regional data, where the differences for growth rates are less notable than for years of schooling. The improvement in labor quality for Africa is much smaller than implied by the increase from an average of one to three years of schooling: a rise in labor quality of only 0.3 percent per year. The relative performance of the industrial countries is greatly improved.

\section{Measures of Factor Shares}

The final step in the estimation of the indexes of TFP growth involves the choice of weights for aggregating the factor inputs. As mentioned above, in a competitive economy those weights could be represented by the shares of income earned by capital and labor respectively; and, to be truly independent of the underlying production function, the weights would need to vary freely across countries and time (as in Divisia-Tornquist indexes). However, reliable measures of factor income shares are not available for most developing countries, and even for the industrial countries, problems arise in dividing the income of the self-employed between the returns to capital and labor.

We have employed fixed weights in aggregating the factor inputs. That procedure is consistent with a much more limited set of production functions; but existing studies provide surprisingly little evidence of major changes in factor shares over time. Instead, most of the debate has been about the absolute level of the capital share. Within the industrial countries, the disagreements are largely reconcilable by relating them to differences in the breadth of the definition of capital and the specific sectors of the economy that are included in the studies ${ }^{41}$ For definitions of capital and output close to ours, Angus Maddison finds that capital's share of income in the major industrial economies is

41. Denison (1967), for example, assigns a low weight to capital because he focuses on output net of depreciation and excludes some of the most capital-intensive sectors, such as housing. In contrast, the studies by Jorgenson and his various coauthors use gross output and often include consumer durables in capital; see, for example, Jorgenson, Gollop, and Fraumeni (1987). 
clustered around 0.3. ${ }^{42}$ Steven Englander and Andrew Gurney calculate factor share ratios (adjusted for the self-employed) for the business sector of the OECD countries, finding that capital's share varies between 0.3 and 0.4 and is largely free of trend ${ }^{43}$

For the developing economies, there has typically been a much broader range of variation. Where national accounts data exist, the reported capital shares are usually well above those of the industrial countries, but the difference is heavily influenced by the large role of the self-employed, whose income is included with that of capital. ${ }^{44}$ Furthermore, it could be a mistake to attribute the higher share to the greater importance of capital in these economies. For example, capital's contribution could be overstated if developing countries systematically suffer from weaker competition and a greater role for monopoly profits.

Parametric estimates, however, have also generally found that the capital elasticity is higher in developing economies. For example, Kim and Lau obtain capital elasticities in excess of 0.4 for the Asian newly industrializing countries, compared with values near 0.3 for the industrial countries; and Ann Harrison obtains coefficients in excess of 0.4 for a larger set of developing economies ${ }^{45}$ Yet there are good reasons for believing that the parametric estimates will be biased upward ${ }^{46}$

We believe, from the existing literature, that a plausible range for the capital share is 0.3 to 0.4 ; and there is also considerable evidence that the capital elasticity is higher in developing economies than in industrial economies. However, to minimize concern about methodological differences in our comparison of growth in East Asia with that in other regions, we use a uniform capital share of 0.35 for the entire sample. We also treat the benefits of education $(H)$ as being embodied in workers, so that the basic production relationship is of the form

$$
Q=A K^{\alpha}(H L)^{(1-\alpha)},
$$

42. Maddison (1987, p. 659).

43. Englander and Gurney (1994) use the average factor share in each country to construct TFP indexes.

44. For four Asian economies, Young (1995) estimates the factor shares with detailed adjustments for the self-employed. For various periods during the last three decades, he obtains a capital share of 0.32 for Korea, 0.29 for Taiwan, 0.53 for Singapore, and 0.37 for Hong Kong. The share appears to be constant over time for Taiwan and Singapore, to fall slightly for Korea, and to rise for Hong Kong.

45. Kim and Lau (1994); Harrison (1996). See, as well, Page (1994).

46. Some evidence is provided in Benhabib and Spiegel (1994, pp. 169-73). 
where $\alpha=0.35$. Thus we report our results in a form that decomposes the growth of output per worker $(q / l)$ into the contributions of the growth of physical capital per worker $(k / l)$, the growth of education per worker $(h)$, and the growth of total factor productivity $(a)$ :

$$
q / l=\alpha(k / l)+(1-\alpha) h+a .
$$

\section{Sources of East Asian Growth}

The growth in output per worker, divided into the contributions of increases in physical capital per worker, education per worker, and total factor productivity, is reported in table 6 for the seven East Asian economies over various subperiods of 1960-94. For comparative purposes, regional aggregates are reported in table 7 . We separate China from the rest of Asia both because of its size and because there are questions about the accuracy of the underlying national accounts data. The United States is also reported separately because of the interest in comparing East Asia today with the other industrial countries during the periods when they were rapidly catching up to the productivity standards of the United States. An alternative, graphic perspective is provided by the summary of the regional indexes on an annual basis in figure 2-again, growth in output per worker is divided into the contribution of increased capital per worker and TFP. ${ }^{47}$

The results are interesting in several respects. First, as stressed by Young, it is quite surprising to note the extent to which the extraordinary growth of East Asia has been driven by factor accumulation, while gains in TFP have been rather modest. ${ }^{48}$ In fact, the division between factor accumulation and TFP growth is actually tilted more toward the former by extension of the analysis to cover a larger number of East Asian countries. While it might be tempting to argue that developing economies can make rapid strides forward simply by accelerating the pace at which they adopt the more efficient technologies of the industrial countries, this does not appear to be an important aspect of the Asian success story. The estimated growth of TFP for the region, 1.1 percent

47. Capital per worker is defined such that capital includes education.

48. See Young $(1994,1995)$. Our results for Korea, Singapore, and Taiwan are very similar to those of Young, allowing for our inclusion of the agricultural sector. 
Table 6. Sources of Growth in East Asia, by Country and Period Percentage points per year

\begin{tabular}{|c|c|c|c|c|}
\hline \multirow[b]{2}{*}{$\begin{array}{l}\text { Country and } \\
\text { period }\end{array}$} & \multirow{2}{*}{$\begin{array}{c}\text { Growth of } \\
\text { output per } \\
\text { worker }\end{array}$} & \multicolumn{3}{|c|}{ Contribution by component } \\
\hline & & $\begin{array}{l}\text { Physical capital } \\
\text { per worker }\end{array}$ & $\begin{array}{c}\text { Education } \\
\text { per } \text { worker }^{\mathrm{b}}\end{array}$ & $\begin{array}{c}\text { Total factor } \\
\text { productivity }\end{array}$ \\
\hline \multicolumn{5}{|l|}{ Indonesia } \\
\hline $1960-94$ & 3.4 & 2.1 & 0.5 & 0.8 \\
\hline $1960-73$ & 2.5 & 0.9 & 0.5 & 1.1 \\
\hline 1973-94 & 4.0 & 2.8 & 0.5 & 0.7 \\
\hline $1973-84$ & 4.3 & 3.3 & 0.5 & 0.5 \\
\hline $1984-94$ & 3.7 & 2.3 & 0.5 & 0.9 \\
\hline \multicolumn{5}{|l|}{ Korea } \\
\hline $1960-94$ & 5.7 & 3.3 & 0.8 & 1.5 \\
\hline $1960-73$ & 5.6 & 3.2 & 0.9 & 1.4 \\
\hline $1973-94$ & 5.8 & 3.4 & 0.7 & 1.6 \\
\hline $1973-84$ & 5.3 & 3.4 & 0.8 & 1.1 \\
\hline 1984-94 & 6.2 & 3.3 & 0.6 & 2.1 \\
\hline \multicolumn{5}{|l|}{ Malaysia } \\
\hline 1960-94 & 3.8 & 2.3 & 0.5 & 0.9 \\
\hline $1960-73$ & 4.0 & 2.4 & 0.5 & 1.0 \\
\hline 1973-94 & 3.7 & 2.3 & 0.5 & 0.9 \\
\hline $1973-84$ & 3.6 & 2.7 & 0.5 & 0.4 \\
\hline $1984-94$ & 3.8 & 1.8 & 0.5 & 1.4 \\
\hline \multicolumn{5}{|l|}{ Philippines } \\
\hline 1960-94 & 1.3 & 1.2 & 0.5 & -0.4 \\
\hline $1960-73$ & 2.5 & 1.3 & 0.6 & 0.7 \\
\hline $1973-94$ & 0.5 & 1.1 & 0.5 & -1.1 \\
\hline $1973-84$ & 1.2 & 2.0 & 0.6 & -1.3 \\
\hline 1984-94 & -0.3 & 0.2 & 0.4 & -0.9 \\
\hline \multicolumn{5}{|l|}{ Singapore } \\
\hline $1960-94$ & 5.4 & 3.4 & 0.4 & 1.5 \\
\hline $1960-73$ & 5.9 & 4.6 & 0.4 & 0.9 \\
\hline $1973-94$ & 5.1 & 2.7 & 0.4 & 2.0 \\
\hline $1973-84$ & 4.3 & 3.1 & 0.2 & 1.0 \\
\hline 1984-94 & 6.0 & 2.3 & 0.6 & 3.1 \\
\hline \multicolumn{5}{|l|}{ Thailand } \\
\hline 1960-94 & 5.0 & 2.7 & 0.4 & 1.8 \\
\hline $1960-73$ & 4.8 & 3.2 & 0.1 & 1.4 \\
\hline $1973-94$ & 5.2 & 2.3 & 0.6 & 2.1 \\
\hline $1973-84$ & 3.6 & 2.0 & 0.5 & 1.1 \\
\hline $1984-94$ & 6.9 & 2.6 & 0.8 & 3.3 \\
\hline \multicolumn{5}{|l|}{ Taiwan } \\
\hline $1960-94$ & 5.8 & 3.1 & 0.6 & 2.0 \\
\hline $1960-73$ & 6.8 & 3.9 & 0.5 & 2.2 \\
\hline 1973-94 & 5.2 & 2.7 & 0.7 & 1.8 \\
\hline $1973-84$ & 4.9 & 3.0 & 0.9 & 0.9 \\
\hline 1984-94 & 5.6 & 2.3 & 0.5 & 2.8 \\
\hline
\end{tabular}

Source: Authors' calculations, as explained in text, based on data from World Data 1995; the data sets of Barro and Lee (1994b), Nehru and Dhareshwar (1993), and Nehru, Swanson, and Dubey (1995); the Penn-World Tables, mark 5.6; and unpublished materials provided by the International Labour Organisation.

a. The contribution of physical capital per worker is its growth rate multiplied by capital's production share $(\alpha=0.35)$.

b. The contribution of education per worker is the growth rate of the labor quality index $(H)$ multiplied by labor's production share ( $1-\alpha=0.65)$.

c. The contribution of TFP is the difference between the growth rate of output per worker and the summed contributions of physical capital per worker and education per worker. 
Table 7. Sources of Growth, by Region and Period ${ }^{\mathrm{a}}$

Percentage points per year

\begin{tabular}{|c|c|c|c|c|}
\hline \multirow[b]{2}{*}{ Region and period } & \multirow{2}{*}{$\begin{array}{c}\text { Growth of } \\
\text { output per } \\
\text { worker }\end{array}$} & \multicolumn{3}{|c|}{ Contribution by component } \\
\hline & & $\begin{array}{c}\text { Physical capital } \\
\text { per worker }\end{array}$ & $\begin{array}{c}\text { Education } \\
\text { per worker }\end{array}$ & $\begin{array}{c}\text { Total factor } \\
\text { productivity }^{\mathrm{d}}\end{array}$ \\
\hline \multicolumn{5}{|l|}{ China } \\
\hline 1960-94 & 4.5 & 1.5 & 0.4 & 2.6 \\
\hline $1960-73$ & 2.2 & 0.4 & 0.4 & 1.4 \\
\hline 1973-94 & 6.0 & 2.2 & 0.4 & 3.3 \\
\hline $1973-84$ & 4.3 & 1.7 & 0.4 & 2.2 \\
\hline 1984-94 & 8.0 & 2.9 & 0.3 & 4.6 \\
\hline \multicolumn{5}{|l|}{ East Asia } \\
\hline 1960-94 & 4.2 & 2.5 & 0.6 & 1.1 \\
\hline $1960-73$ & 4.2 & 2.3 & 0.5 & 1.3 \\
\hline 1973-94 & 4.2 & 2.5 & 0.6 & 1.0 \\
\hline $1973-84$ & 4.0 & 2.8 & 0.6 & 0.5 \\
\hline 1984-94 & 4.4 & 2.2 & 0.6 & 1.6 \\
\hline \multicolumn{5}{|l|}{ South Asia } \\
\hline 1960-94 & 2.3 & 1.1 & 0.3 & 0.8 \\
\hline $1960-73$ & 1.8 & 1.4 & 0.3 & 0.1 \\
\hline 1973-94 & 2.6 & 0.9 & 0.3 & 1.3 \\
\hline $1973-84$ & 2.5 & 0.9 & 0.4 & 1.2 \\
\hline 1984-94 & 2.7 & 1.0 & 0.3 & 1.5 \\
\hline \multicolumn{5}{|l|}{ Africa } \\
\hline 1960-94 & 0.3 & 0.8 & 0.2 & -0.6 \\
\hline $1960-73$ & 1.9 & 1.3 & 0.2 & 0.3 \\
\hline 1973-94 & -0.6 & 0.4 & 0.2 & -1.3 \\
\hline 1973-84 & -0.6 & 1.2 & 0.2 & -2.0 \\
\hline 1984-94 & -0.6 & -0.4 & 0.3 & $\begin{array}{l}-0.4 \\
\text { (continued) }\end{array}$ \\
\hline
\end{tabular}

Source: See table 6

a. Computed using the eighty-eight country sample. Regional averages are calculated by weighting each country by its average GDP over 1960-94, as measured in 1985 dollars.

b. The contribution of physical capital per worker is its growth rate multiplied by capital's production share $(\alpha=0.35)$.

per year over the thirty-four-year period, is about the same as that of the industrial countries other than the United States, and only marginally above that of South Asia. Gains in TFP account for only one-fourth of the region's growth in output per worker over the past three decades. The situation may be changing, as there is some evidence of more extensive gains in TFP in the period 1984-94. There are also some important differences among individual countries: TFP growth is higher for Taiwan, and the performance of the Philippines is strikingly poor.

However, while the rate of TFP growth in East Asia may seem low 
Table 7. Sources of Growth, by Region and Period ${ }^{\text {(continued) }}$

Percentage points per year

\begin{tabular}{|c|c|c|c|c|}
\hline \multirow[b]{2}{*}{ Region and period } & \multirow{2}{*}{$\begin{array}{c}\text { Growth of } \\
\text { output per } \\
\text { worker }\end{array}$} & \multicolumn{3}{|c|}{ Contribution by component } \\
\hline & & $\begin{array}{c}\text { Physical capital } \\
\text { per worker }\end{array}$ & 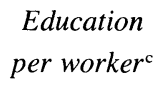 & $\begin{array}{l}\text { Total factor } \\
\text { productivity }^{\mathrm{d}}\end{array}$ \\
\hline \multicolumn{5}{|l|}{ Middle East } \\
\hline 1960-94 & 1.6 & 1.5 & 0.5 & -0.3 \\
\hline $1960-73$ & 4.7 & 2.0 & 0.4 & 2.3 \\
\hline $1973-94$ & -0.3 & 1.1 & 0.5 & -1.9 \\
\hline $1973-84$ & 0.5 & 2.2 & 0.6 & -2.2 \\
\hline 1984-94 & -1.1 & -0.0 & 0.5 & -1.5 \\
\hline \multicolumn{5}{|l|}{ Latin America } \\
\hline $1960-94$ & 1.5 & 0.9 & 0.4 & 0.2 \\
\hline $1960-73$ & 3.4 & 1.3 & 0.3 & 1.8 \\
\hline $1973-94$ & 0.3 & 0.6 & 0.4 & -0.8 \\
\hline $1973-84$ & 0.4 & 1.1 & 0.4 & -1.1 \\
\hline 1984-94 & 0.1 & 0.1 & 0.4 & -0.4 \\
\hline \multicolumn{5}{|l|}{ United States } \\
\hline 1960-94 & 1.1 & 0.4 & 0.4 & 0.3 \\
\hline $1960-73$ & 1.9 & 0.5 & 0.6 & 0.8 \\
\hline $1973-94$ & 0.6 & 0.3 & 0.2 & 0.1 \\
\hline $1973-84$ & 0.2 & 0.3 & 0.5 & -0.5 \\
\hline 1984-94 & 0.9 & 0.3 & -0.0 & 0.7 \\
\hline \multicolumn{5}{|c|}{ Other industrial countries } \\
\hline 1960-94 & 2.9 & 1.5 & 0.4 & 1.1 \\
\hline $1960-73$ & 4.8 & 2.3 & 0.4 & 2.2 \\
\hline 1973-94 & 1.7 & 1.0 & 0.4 & 0.4 \\
\hline $1973-84$ & 1.8 & 1.1 & 0.6 & 0.2 \\
\hline 1984-94 & 1.7 & 0.8 & 0.2 & 0.7 \\
\hline
\end{tabular}

c. The contribution of education per worker is the growth rate of the labor quality index $(H)$ multiplied by labor's production share $(1-\alpha=0.65)$.

d. The contribution of TFP is the difference between the growth rate of output per worker and the summed contributions of physical capital per worker and education per worker.

in an absolute sense, it is far better than that achieved by some other developing regions. It has been negative in Africa and the Middle East and nearly zero in Latin America. The real surprise is that TFP growth is low in all of the developing countries. We would have expected that the ability to borrow existing technology and management expertise from the advanced industrial nations would make the process easier for those who came after. That does not appear to be true.

Second, the contribution of educational advances, if adequately measured by wage differentials, is larger in East Asia than in other regions, but is still a relatively minor part of the story. Their contribution is 
Figure 2. Output per Worker and Its Components, by Region, 1960-94a

Index, $1960=1$
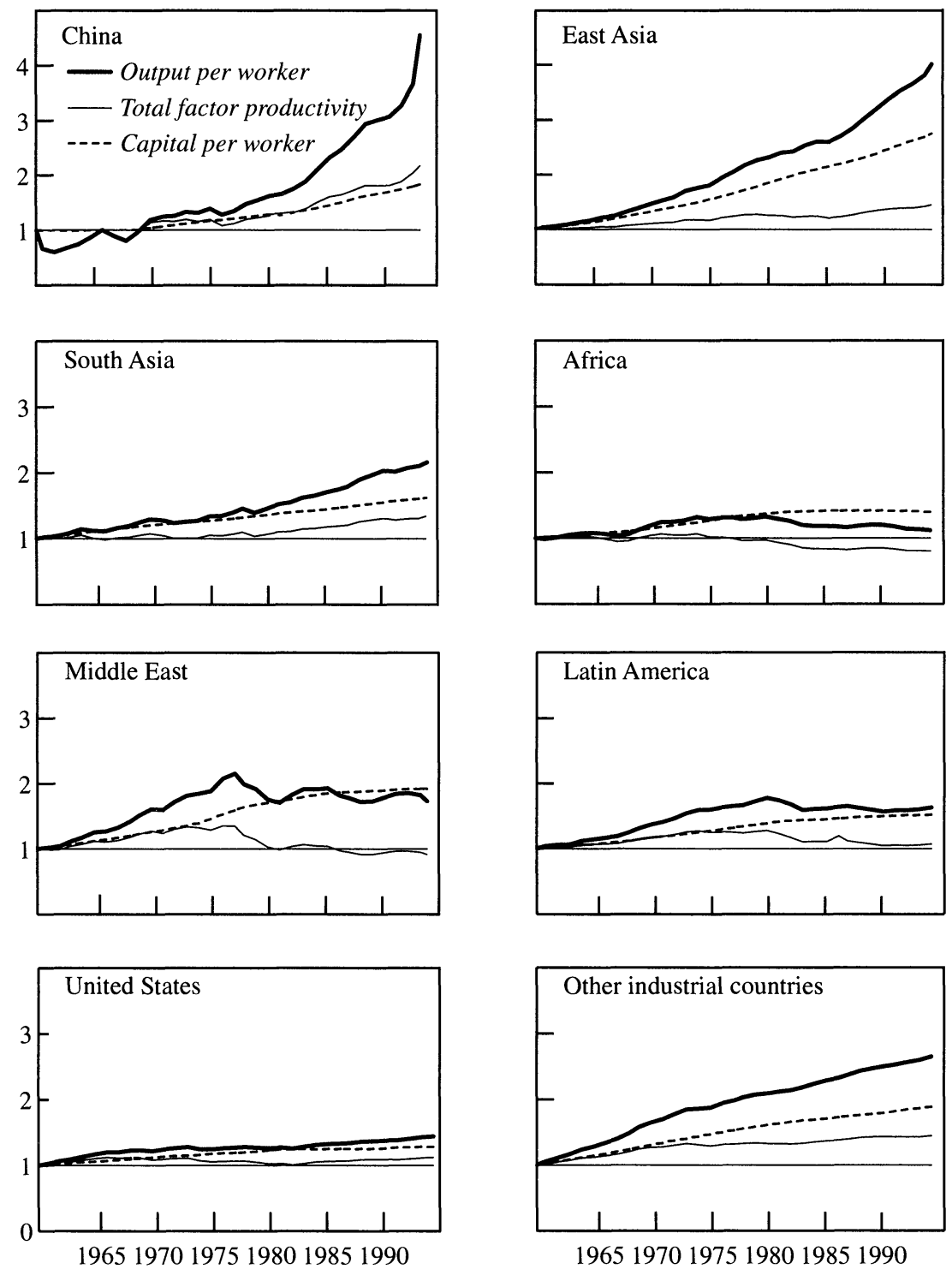

196519701975198019851990

Source: See table 6.

a. The level of capital per worker is an indexed sum of the two components of capital: physical capital per worker and education per worker. These components are weighted by the production shares of physical capital and labor, respectively. 
largest for Korea and Taiwan, but the intraregional variation is small. If there are large spillover effects, taking account of education raises additional questions about the modest growth of TFP because the spillovers would be reflected in larger TFP gains for countries with major improvements in education, such as those in East Asia.

Furthermore, East Asia stands out in the extent to which the countries of the region have avoided the large reversals of TFP growth that have been common elsewhere, such as in Latin America in the 1980s and in the Middle East since the mid-1970s. This is particularly evident for the late 1970s and early 1980s, when the global oil and financial shocks and war proved so costly to other regions. In contrast, figure 2 shows that the major East Asian countries righted their economies and resumed growth more quickly than those in other regions.

In addition, there does seem to be some basis for questioning the magnitude of growth reported for China in the 1980s because the gain in TFP is so large and is out of line with that experienced by the other East Asian economies at similar stages of their development. Only in China does the contribution of TFP growth exceed that of capital per worker. In their latest update of the Penn-World Tables, Robert Summers and Alan Heston argue that the official estimates of China's GDP understate the level of output and overstate its growth. ${ }^{49}$ Their basic point, that inflation is underestimated and thus growth overestimated, is supported by a recent study concluding that output growth in the industrial sector has been overstated ${ }^{50}$ In addition, it is consistent with the puzzling depreciation in the reported Chinese real exchange rate, which today is at about one-third of its 1980 level. Real depreciation might be expected as part of the process of economic liberalization, but the magnitude and sustained nature of the decline is unexpected. Generally, real exchange rates rise with development. In China's case, the decline in the exchange rate has been large enough to eliminate any evidence of real growth in the dollar-denominated measure of GDP. One explanation for such a result is that the official statistics underestimate the inflation rate, overstating real growth. The growth of the Chinese real GDP in the PWT is about the same as that reported in the official data for the period 1960-80, but for 1980-92 the PWT growth rate is 5 percent, as compared with the 9 percent official rate that we use.

49. Summers and Heston (1994).

50. Jefferson, Rawski, and Zheng (1995). 
Of the other regions, South Asia seems to have enjoyed considerably improved productivity performance in the 1980s, after a decade of very weak performance. A larger portion of the growth of these economies has been the result of improvements in TFP than is true for East Asia. Africa stands out for very poor performance: output per worker has increased by an annual average of only 0.3 percent over the past three decades, and TFP growth has been highly negative. Finally, the 1980s may have been a lost decade for Latin America from the perspective of growth in output per worker, but there is an even longer history of low rates of growth in the TFP component. In fact, it is interesting that after the 1973 oil crisis, all of the regions of the world except Asia experienced a sharp slowing of growth from which they have yet to recover.

We recompute the accounts using alternative values of 0.3 and 0.4 for the capital share. Those results, under both the base case assumption of a 7 percent return to education and the alternative 12 percent return, are summarized in table 8 . As a region, East Asia exhibits the greatest sensitivity to the choice of the parameter values because it accumulates both physical capital and education faster than do other regions. An increase in the weight attached to physical capital accumulation increases capital's contribution and reduces the residual contribution of TFP by 0.6 percentage points per year over the period 1960-94. An increase in the assumed return to education from 7 to 12 percent would further reduce the contribution of TFP by 0.4 percentage point. Overall, the contribution of TFP could range from a high of 1.4 percentage points per year to a low of 0.4 . We interpret this result to imply that it would take even more extreme values to change the fundamental conclusion that growth in East Asia is dominated by factor accumulation.

\section{Productivity Growth versus Capital Accumulation}

It is clear that the Asian economies are different in terms of their overall output growth, but there is considerably less agreement about why this is so. Although their success has generated a vast empirical literature directed toward explaining the source of their growth, that research has not eliminated the controversy. In part, the continued debate results from the difficulties of using cross-national analysis to identify key correlations between aggregate output growth and various 
Table 8. Sources of Growth under Alternative Assumptions of Capital Share and Returns to Education, by Region, 1960-94a

Percentage points, except as indicated

\begin{tabular}{|c|c|c|c|c|c|}
\hline \multicolumn{2}{|c|}{ Region and assumption } & \multirow{3}{*}{$\begin{array}{c}\text { Growth of } \\
\text { output per } \\
\text { worker }\end{array}$} & \multirow{2}{*}{\multicolumn{3}{|c|}{ Contribution by component }} \\
\hline \multirow{2}{*}{$\begin{array}{l}\text { Region and } \\
\text { return to } \\
\text { education }^{\mathrm{b}}\end{array}$} & \multirow{2}{*}{$\begin{array}{c}\text { Capital's } \\
\text { production } \\
\text { share }^{c}\end{array}$} & & & & \\
\hline & & & $\begin{array}{l}\text { Physical capital } \\
\text { per worker }\end{array}$ & 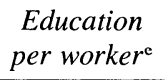 & $\begin{array}{l}\text { Total factor } \\
\text { productivity }\end{array}$ \\
\hline \multicolumn{6}{|l|}{ China } \\
\hline \multirow[t]{2}{*}{7 percent } & 0.3 & 4.5 & 1.3 & 0.4 & 2.7 \\
\hline & 0.4 & 4.5 & 1.8 & 0.4 & 2.4 \\
\hline \multirow[t]{2}{*}{12 percent } & 0.3 & 4.5 & 1.3 & 0.9 & 2.3 \\
\hline & 0.4 & 4.5 & 1.8 & 0.7 & 2.0 \\
\hline \multicolumn{6}{|l|}{ East Asia } \\
\hline \multirow[t]{2}{*}{7 percent } & 0.3 & 4.2 & 2.1 & 0.6 & 1.4 \\
\hline & 0.4 & 4.2 & 2.8 & 0.5 & 0.8 \\
\hline \multirow[t]{2}{*}{12 percent } & 0.3 & 4.2 & 2.1 & 1.0 & 1.0 \\
\hline & 0.4 & 4.2 & 2.8 & 0.9 & 0.4 \\
\hline \multicolumn{6}{|l|}{ South Asia } \\
\hline \multirow{2}{*}{7 percent } & 0.3 & 2.3 & 1.0 & 0.3 & 1.0 \\
\hline & 0.4 & 2.3 & 1.3 & 0.3 & 0.7 \\
\hline \multirow{2}{*}{12 percent } & 0.3 & 2.3 & 1.0 & 0.7 & 0.6 \\
\hline & 0.4 & 2.3 & 1.3 & 0.6 & 0.4 \\
\hline \multicolumn{6}{|l|}{ Africa } \\
\hline \multirow[t]{2}{*}{7 percent } & 0.3 & 0.3 & 0.7 & 0.2 & -0.6 \\
\hline & 0.4 & 0.3 & 0.9 & 0.2 & -0.7 \\
\hline \multirow[t]{2}{*}{12 percent } & 0.3 & 0.3 & 0.7 & 0.5 & -0.8 \\
\hline & 0.4 & 0.3 & 0.9 & 0.4 & -0.9 \\
\hline \multicolumn{6}{|l|}{ Middle East } \\
\hline \multirow[t]{2}{*}{7 percent } & 0.3 & 1.6 & 1.2 & 0.5 & -0.1 \\
\hline & 0.4 & 1.6 & 1.7 & 0.4 & -0.5 \\
\hline \multirow[t]{2}{*}{12 percent } & 0.3 & 1.6 & 1.2 & 1.0 & -0.6 \\
\hline & 0.4 & 1.6 & 1.7 & 0.8 & -0.9 \\
\hline \multicolumn{6}{|l|}{ Latin America } \\
\hline \multirow[t]{2}{*}{7 percent } & 0.3 & 1.5 & 0.8 & 0.4 & 0.3 \\
\hline & 0.4 & 1.5 & 1.0 & 0.3 & 0.1 \\
\hline \multirow[t]{2}{*}{12 percent } & 0.3 & 1.5 & 0.8 & 0.7 & 0.0 \\
\hline & 0.4 & 1.5 & 1.0 & 0.6 & -0.1 \\
\hline \multicolumn{6}{|c|}{ Industrial countries } \\
\hline \multirow[t]{2}{*}{7 percent } & 0.3 & 2.3 & 1.0 & 0.4 & 1.0 \\
\hline & 0.4 & 2.3 & 1.3 & 0.3 & 0.7 \\
\hline \multirow[t]{2}{*}{12 percent } & 0.3 & 2.3 & 1.0 & 0.6 & 0.7 \\
\hline & 0.4 & 2.3 & 1.3 & 0.5 & 0.5 \\
\hline
\end{tabular}

Source: See table 6.

a. Computed using the eighty-eight country sample. Regional averages are calculated by weighting each country by its average GDP over 1960-94, as measured in 1985 dollars.

b. The return to each additional year of schooling; see text for details.

c. Presented as a decimal.

d. The contribution of physical capital per worker is its growth rate multiplied by capital's production share $(\alpha)$.

e. The contribution of education per worker is the growth rate of the labor quality index $(H)$ multiplied by labor's production share $(1-\alpha)$.

f. The contribution of TFP is the difference between the growth rate of output per worker and the summed contributions of physical capital per worker and education per worker. 
policy measures. The regression analysis, in particular, has been frustrated by the instability of results in the face of seemingly minor changes in specification. ${ }^{51}$ In addition, growth and its proximate determinants are all endogenous elements, making it hard to infer causality.

Similar questions could be raised about our decomposition of growth in output per worker into capital accumulation and TFP growth. Distinguishing between the two could be difficult for at least two reasons. First, technical advances might be embodied in new capital. Second, by raising the returns to capital, increased TFP might induce greater capital accumulation. Thus, as a point of departure, it is worth asking whether the growth accounting exercise actually yields a meaningful decomposition and whether it allows one to say anything more definite about the ways in which the East Asian countries differ from others.

As one approach to these issues, we use regression analysis to relate economic growth to some basic measures of initial conditions and the external environment. We then attempt to determine the extent to which, conditional on these basic determinants, the East Asian growth experience differs from that of other economic regions. The same exercise is then performed on the two components, factor accumulation and TFP growth.

In developing the indicators of initial and external conditions, we have borrowed heavily from prior work by Barro and Lee. ${ }^{52} \mathrm{We}$ are able to replicate the essential features of their statistical results for our different sample of countries and somewhat different measure of output per worker. Our basic indicators are presented in table 9. The initial level of income per capita (in international prices) is included to capture the phenomenon of catchup, and life expectancy and years of schooling are included as measures of health and education, respectively. Variations in the external environment are represented by the mean and standard deviation of the annual change in each country's terms of trade

51. Levine and Renelt (1992).

52. Barro and Lee (1994b). Since we do not find any role in our data set for the Barro-Lee measure of revolutions and political instability, it is excluded from the following analysis. Nor do we attempt to differentiate between the roles of male and female education levels. The most important difference in our analysis is that we adjust for changes in labor force participation by using GDP per worker as the dependent variable; Barro and Lee used per capita GDP. In addition, the initial income level is measured as a percent of per capita income of the United States. 
Table 9. Initial Conditions and External Shocks, by Region and Country ${ }^{\mathrm{a}}$ Units as indicated

\begin{tabular}{|c|c|c|c|c|c|c|}
\hline $\begin{array}{l}\text { Region and } \\
\text { country }\end{array}$ & $\begin{array}{c}\text { Income } \\
\text { per capita }^{\mathrm{b}}\end{array}$ & $\begin{array}{c}\text { Life } \\
\text { expectancy }\end{array}$ & $\begin{array}{c}\text { Years of } \\
\text { schooling }^{\mathrm{d}}\end{array}$ & $\begin{array}{l}\text { Change } \\
\text { in terms } \\
\text { of trade }\end{array}$ & $\begin{array}{c}\text { Standard } \\
\text { deviation } \\
\text { of terms } \\
\text { of trade }\end{array}$ & $\begin{array}{c}\text { Investment } \\
\text { share }^{\mathrm{g}}\end{array}$ \\
\hline China & 5.4 & 36.3 & 2.1 & -0.4 & 5.0 & 20.5 \\
\hline East Asia & 11.4 & 55.0 & 3.3 & -0.0 & 11.2 & 21.6 \\
\hline Indonesia & 5.8 & 41.5 & 1.6 & 5.4 & 25.6 & 17.1 \\
\hline Korea & 8.7 & 54.2 & 4.4 & -1.5 & 5.9 & 23.7 \\
\hline Malaysia & 15.0 & 54.3 & 2.8 & -1.2 & 9.9 & 23.5 \\
\hline Philippines & 11.5 & 53.1 & 4.2 & -1.7 & 10.5 & 15.3 \\
\hline Singapore & 16.6 & 63.7 & 3.2 & 1.6 & 5.7 & 31.2 \\
\hline Thailand & 9.6 & 52.7 & 3.2 & -2.5 & 8.1 & 18.1 \\
\hline Taiwan & 12.3 & 65.4 & 3.8 & 0.0 & 12.8 & 22.0 \\
\hline South Asia & 7.8 & 47.7 & 1.7 & -1.2 & 10.4 & 9.3 \\
\hline Africa & 9.2 & 42.1 & 1.2 & -1.3 & 16.4 & 8.8 \\
\hline Middle East & 15.7 & 54.5 & 2.6 & 1.7 & 14.3 & 17.2 \\
\hline Latin America & 22.1 & 55.4 & 3.2 & -0.9 & 15.4 & 15.6 \\
\hline Industrial countries & 55.6 & 69.3 & 6.4 & -1.2 & 8.0 & 25.9 \\
\hline Total & 25.3 & 55.1 & 3.4 & -0.7 & 12.9 & 17.0 \\
\hline
\end{tabular}

Source: Per capita income and investment share are authors' calculations based on international price data from the PennWorld Tables, mark 5.6. Data on life expectancy are from the data set constructed by Barro and Lee (1994b); and for years of schooling, from the data sets constructed by Barro and Lee (1994a) and Nehru. Swanson, and Dubey (1995). Terms of trade are the authors' calculations based on data from World Data 1995.

a. Computed for the eighty-eight country sample. Regional averages are simple averages.

b. Percent of U.S. level, 1960.

c. Years, 1960.

d. Average for the adult population, 1965 .

e. Mean of annual log changes $(\times 100), 1965-92$.

f. Standard deviation of annual log changes $(\times 100), 1965-92$

g. Average percent of GDP, 1960-94.

(defined as the ratio of the price index of exports to the price index of imports, both measured in dollars).

The results of our regression analysis are presented in table 10. As shown in column 1, these conditioning variables account for nearly half of the cross-national variation in per capita GDP growth for the period 1960-94. Except for the catchup measure (initial income), they do relatively little to explain why the East Asian economies have grown faster than the average: the means of the conditioning variables for East Asia, shown in table 9, do not differ significantly from those of the total sample. They do, however, highlight some important differences between East Asia and other individual regions. Comparison of East Asia and Latin America shows that about one-fourth of the gap in growth rates can be attributed to differing magnitudes of terms-of-trade 


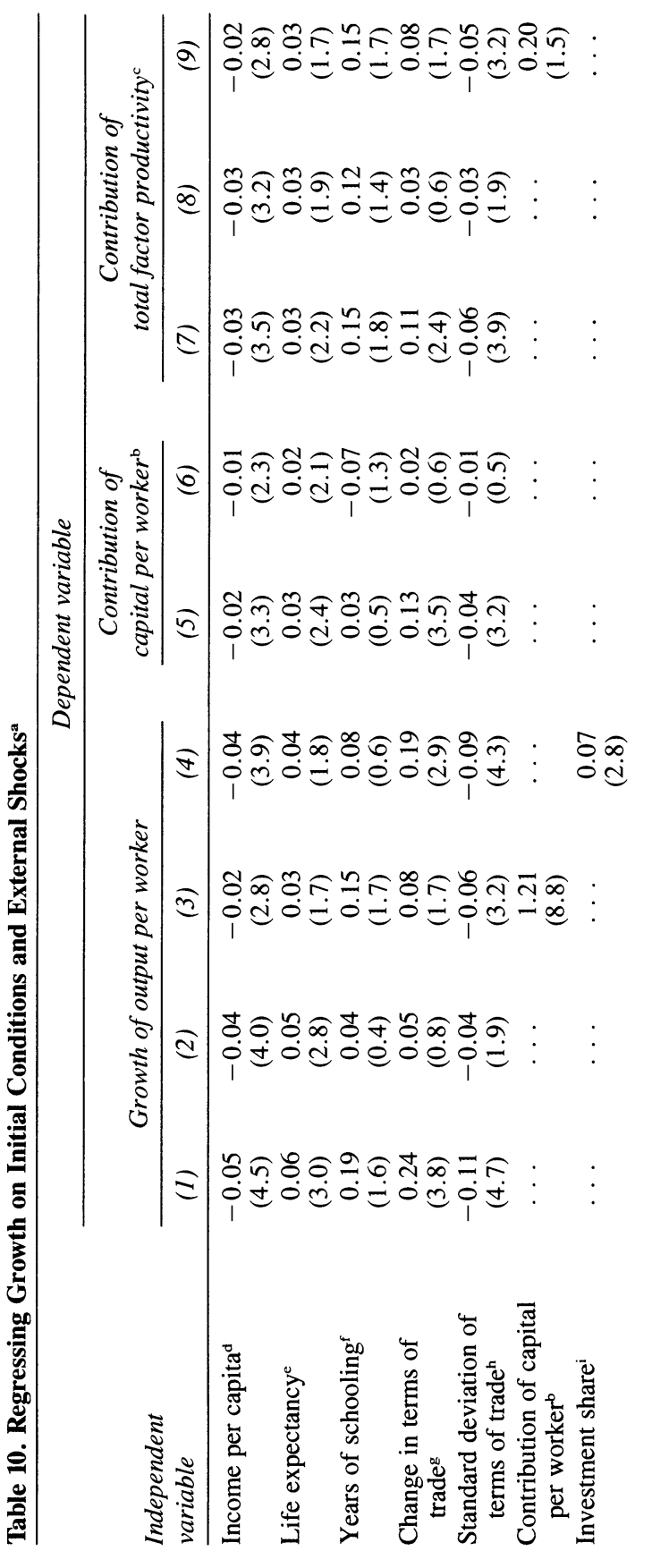




$$
\begin{aligned}
& \vdots \quad \vdots \quad \vdots \quad \vdots \quad 0
\end{aligned}
$$

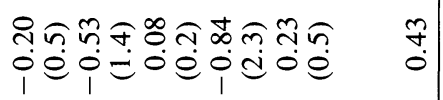

$$
\begin{aligned}
& \vdots \vdots \vdots \vdots \vdots
\end{aligned}
$$

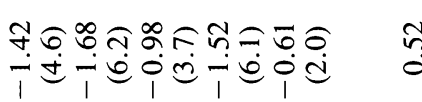

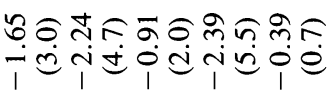

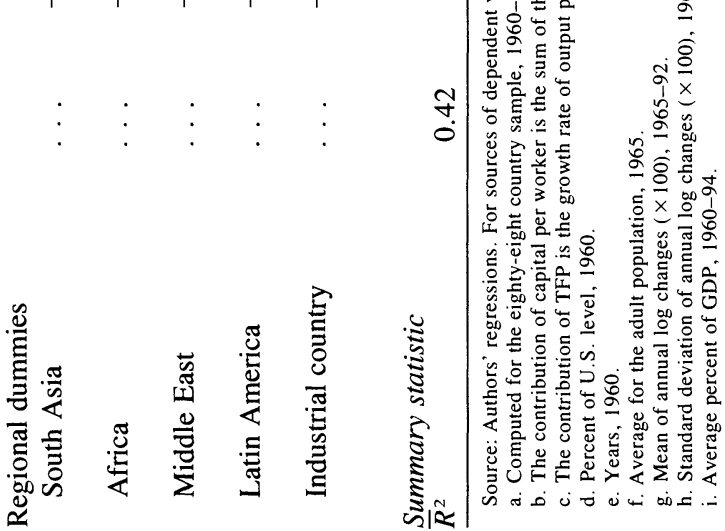


shocks. By contrast, differing external conditions explain little of East Asia's rapid growth relative to South Asia. The higher education and life expectancy in East Asia, however, are worth about 0.75 percentage point per year of higher growth.

The results of adding fixed regional effects are reported in column 2. Relative to the base region, East Asia, the others have considerably lower growth rates. The difference is small for the industrial countries, but it is large (over 2 percentage points per year) for Latin America and sub-Saharan Africa. The regional effects also reduce the significance of education and the terms of trade, while raising the overall adjusted $R^{2}$ to 0.62 .

The contribution of capital accumulation is included as a right-handside variable in column 3 . Recognizing that it is likely to be highly endogenous, we interpret the regression as indicating whether the growth accounting has resulted in a meaningful measure of the contribution of capital accumulation. It is reassuring to note that the coefficient on the capital accumulation term is not significantly different from unity and that it raises the adjusted $R^{2}$ to $0.70 .^{53}$ Column 4 reports the result of substituting the investment rate for the capital accumulation term. The use of the investment share as a proxy for capital accumulation results in a much lower overall adjusted $R^{2}, 0.46$, leaving a much larger residual estimate of the contribution of productivity gains to economic growth. ${ }^{54}$

The remaining columns of table 10 report the results from parallel regressions for the contributions of capital accumulation and TFP growth. Here it is interesting to note that while the set of conditioning variables explains a significant portion of the variation in both capital accumulation and TFP growth, the regional effects are very large and significant for capital accumulation but marginal for TFP growth. The addition of the regional dummy variables raises the adjusted $R^{2}$ by 0.28 for capital accumulation but by only 0.07 for TFP growth. Because the regional effects are measured relative to East Asia, the implication is that East Asia stands out from the other regions in the magnitude of its

53. Combining the capital accumulation term with fixed regional effects results in a coefficient of 0.95 , and only the regional measure for Latin America retains statistical significance.

54. This regression is based on the investment share as given in international prices. The national price measure results in an even lower $\bar{R}^{2}, 0.42$. 
capital accumulation, but not for TFP growth. Furthermore, as shown in regression equation 9, the measure of capital accumulation is essentially orthogonal to the estimate of TFP growth.

These same issues of the relative importance of TFP and capital formation appear in a slightly different context as part of the new endogenous growth theory literature. In many such models, TFP and capital per worker are expected to be highly correlated, both across countries and over time. Thus the conclusion from our regression analysis - that, controlling for differences in initial conditions and the external environment, growth in TFP is largely orthogonal to that of capital per worker-is surprising.

It is important to note that the correlation between TFP growth and factor accumulation is sensitive to the choice of the capital elasticity. Assuming a higher capital share tends to reduce the residual measure of TFP growth and, consequently, to lower the correlation between productivity and accumulation. Our assumption of 0.35 is a relatively low estimate for the nonindustrial economies, however. Thus, if anything, we would expect the correlation to be overstated in our data.

The issue of correlation is explored more fully in figure 3. Looking first at the industrial countries, the upper panels distinguish between the experience of 1960-73, when many of these countries had high rates of investment and were actively engaged in catching up with the technological leader (the United States), and the period of a common slowdown in growth after 1973. We expect to find a positive correlation between TFP growth and capital accumulation; previous studies have reported high correlations, both over long periods and in recent decades. ${ }^{55}$ Indeed, that is exactly what emerges in our data for the period before 1973. However, the correlation is modest: an adjusted $R^{2}$ of 0.38 . In contrast, the upper right-hand panel shows no evidence of a relationship after 1973. Some reduction of the correlation might be expected as marginal returns on investments are equalized and the gap between the leader and its followers is reduced. Those projects with the largest advances in technology presumably have high relative returns and would be among the first to be undertaken in all cases. Thus TFP growth would not be reflected in variations of investment at the margin. Still, the disappearance of the relationship is quite surprising.

55. See, for example, Baumol, Nelson, and Wolff (1994), and Grossman and Helpman (1994). 


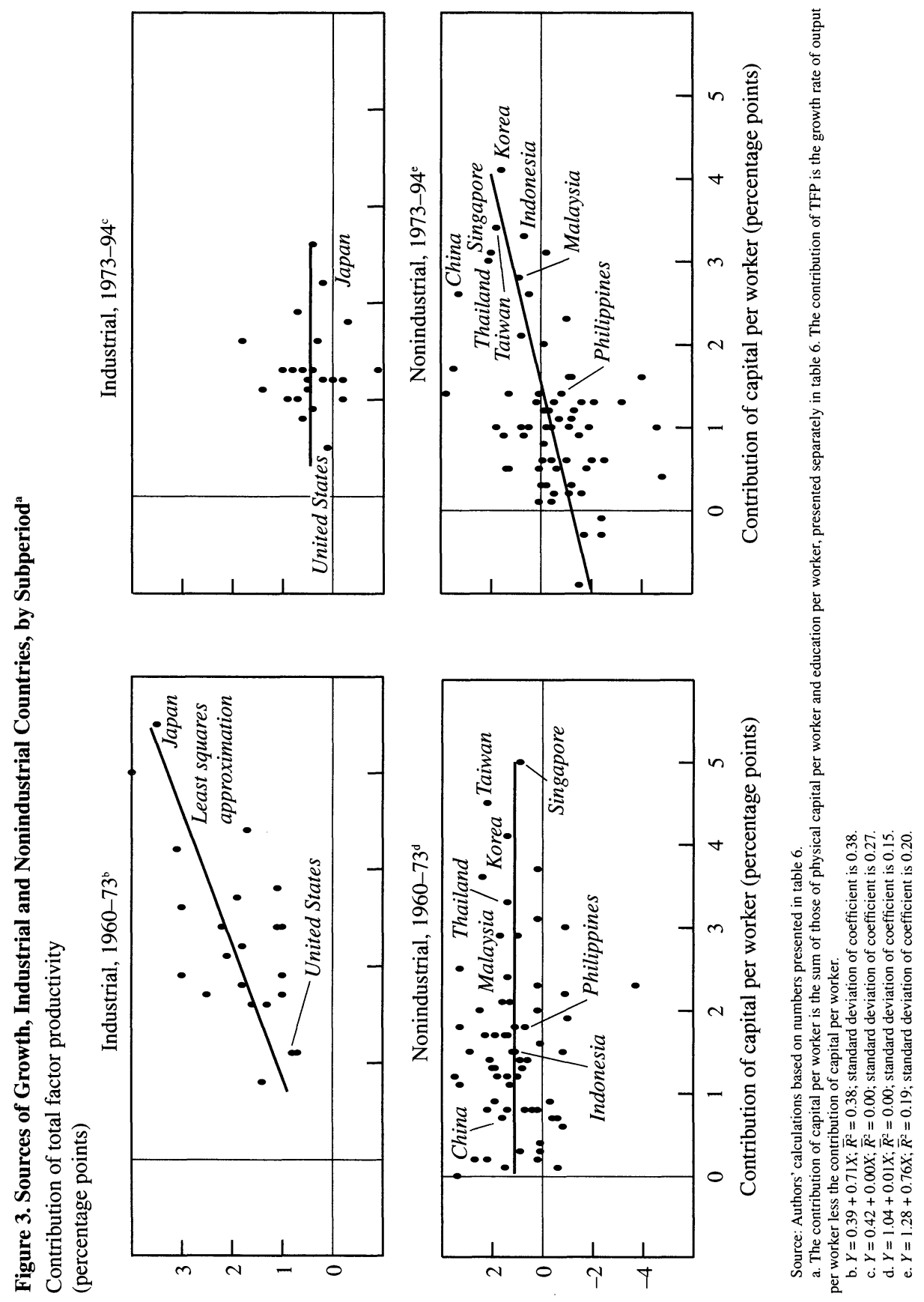


The story for the nonindustrial economies is essentially the opposite of that for the industrial economies. Before 1973, there appears to be no correlation between TFP growth and capital accumulation (lower left-hand panel). Again, it is evident that while the East Asian economies exhibit relatively rapid capital accumulation, they are not unusual in terms of productivity. After 1973 a modest correlation emerges, but largely as the result of developments outside of East Asia: capital accumulation declines and TFP collapses. Meanwhile, the East Asian countries continue to accumulate capital rapidly and to maintain moderate rates of productivity growth.

These results offer striking support to Young's argument, discussed in the introduction. The East Asian economies are unusual primarily in regard to capital accumulation, not TFP growth. The regional coefficients are highly negative and significant for overall growth and capital accumulation, but they are small and largely insignificant for TFP growth. This outcome is not very encouraging either for the argument that the East Asian experience reflects the benefits of open, liberalized markets, or for the view that it illustrates the efficiency gains of an activist governmental industrial policy. Most of these policies are expected to operate by affecting the level and growth of TFP, but there is little about the behavior of TFP in East Asia to be explained. Instead, it appears that the East Asian economies do well because they are willing to make the sacrifices necessary to accumulate capital at very high rates.

\section{The Role of Government}

The role of government has emerged as the most controversial aspect of the East Asian growth experience. The debate is not about whether policy mattered, but over which measures paid off and their relative importance. Although we cannot hope to resolve these issues, we believe that inadequate attention has been devoted to assessing the channels through which policy operated and that the growth accounts provide a basis for distinguishing the effect of policies on factor accumulation from improvements in the efficiency with which the factors were used. Indeed, the above analysis suggests that any claims that 
such policies "worked" by generating large gains in productivity should be viewed with suspicion.

Government is often cited as a major actor in the turnaround of East Asia-a region whose economic prospects seemed dismal in the early 1960s. Growth was slow. Most countries had very low rates of saving and investment; some were heavily dependent on foreign aid. At the time, external assessments of East Asia's prospects were typically very pessimistic, relative to those for Latin America and Africa. Indeed, one World Bank study considered the Philippines the country most likely to succeed. ${ }^{56}$ Since the early 1960 s, each of the currently high-performing East Asian countries has initiated significant policy changes, although there has been considerable variation both in the timing and in many features of the policies implemented, as discussed further below. While many of these economies experienced difficulties along the way, the rapidity and persistence of their subsequent growth has been phenomenal.

The policy measures that have been suggested as contributing to East Asia's success can be divided into two groups. The first comprises policies that are now generally agreed to have played a positive role in both capital accumulation and productivity gains. These include stable macroeconomic policy (albeit defined in somewhat different ways) and the promotion of education. The policies in the second group have been more controversial. Trade policy (more specifically, openness or outward orientation) is often cited as a central element of the region's success; however, definitions of openness vary widely, as do the views on its importance. Most controversial are the different types of selective intervention that have been pursued to varying degrees over the years by governments in the region. Since export promotion was often one of the objectives of intervention, there is some overlap between policies of intervention and outward orientation. ${ }^{57}$

56. World Bank (1993b, p. 14).

57. There is a very large literature assessing the role of policy in rapid East Asian growth. Recent studies that emphasize the importance of market friendly policies include World Bank (1993a) and Krueger (1995). Studies that stress the effects of selective intervention include Amsden (1994) and Fishlow and others (1994). Views about the importance of outward orientation range from Sachs and Warner (1995), who argue that it is the most important element of government policy, to Rodrik $(1994,1995)$, who argues that export orientation could not have played a significant role. Easterly (1995) and Easterly and others (1993) argue that good luck may have been more important than good policy. All of these studies, in turn, provide additional references to the literature. 
It is striking that the controversy focuses on the role of policies that are presumed to operate by promoting growth in TFP. As one analyst remarks, "Central to the debate ... is industrial policy, defined as government efforts to alter industrial structures to promote productivitybased growth." ${ }_{58}$ Our decomposition clearly implies that this debate is misplaced. The search for lessons from high Asian growth should focus on the magnitude and persistence of capital accumulation, not on productivity gains. Indeed, if outward orientation and selective intervention do work, it may well be through their effects on rates of investment and saving.

It is also striking that the same group of successful economies has been used to illustrate the purported benefits of extremely differentand conflicting - policy strategies. Those Western economists who tend to stress the benefits of free markets frequently cite East Asia as evidence that a relatively laissez-faire approach pays off. According to this view, these economies prospered due to the establishment of relatively open trading regimes and other market friendly policy reforms. By contrast, Asian economists and policymakers are more likely to describe their underlying policy strategy as sequential industrial targeting, based on the Japanese model initiated in the 1950s. ${ }^{59}$ Yet neither they nor most Western economists would classify Japanese policy during $1950-70$ as an example of a market friendly approach.

For a variety of reasons, it is difficult to draw definitive conclusions about which policies worked and why. Policies are often implemented together as a group, confounding efforts to tease out the separate effects of the individual measures. Cross-country (or panel) regression studies require simple indicators of policy that typically capture actual differences poorly and suffer from measurement error. Arguably, the available measures of trade regime and industrial targeting - the areas of most controversy - are even more problematic than measures of fiscal, monetary, and exchange rate policy. The fact that most policy variables should be considered endogenous makes causal interpretations of these regressions suspect. On the other hand, while case study approaches can yield much clearer pictures of what happened in individual (or small groups of) countries, they typically do not have adequate checks on

58. Kwon (1994, p. 635).

59. See, for example, Ito $(1992,1994)$ and Singh (1994). 
their conclusions, since they provide limited comparison with performance in other countries that have pursued similar policies. However, it is interesting to note that the detailed studies highlight disparities among policies followed by the high-growth East Asian countries. We focus below on the roles of macroeconomic policies and trade policies. ${ }^{60}$ The remainder of this section provides some background information about the initial situation, policy, and performance in East Asia, and then turns to an empirical analysis of the links between policy and economic growth.

\section{East Asian Policy: An Overview}

As a starting point, it is important to recognize that East Asia is composed of very diverse countries; only a Westerner would lump them together! The population data in table 1 show the considerable range in size from a tiny city state (Singapore) to small countries (Malaysia and Taiwan), moderate sized countries (Korea, Thailand, and the Philippines), and the relatively populous Indonesia. While some countries, such as Korea, are relatively poor in resources, others, such as Indonesia, are richly endowed and face the special problems of commodity booms and busts. The fact that Indonesia comprises thousands of islands raises another set of unique issues. Furthermore, Korea is ethnically quite homogeneous, but the same cannot be said of Malaysia.

Before the onset of rapid growth, there was considerable intraregional variation in economic and social conditions. The seven countries were at very different developmental stages. Indonesia and Thailand began their growth periods with very high percentages of the labor force in agriculture (62 percent and 75 percent, respectively). In 1965, Korea and Taiwan had relatively high initial levels of education, but average years of schooling were only 1.6 in Indonesia and 2.8 in Malaysia (see table 9). Per capita incomes in Singapore and Malaysia were substantially higher than those in Korea, Thailand, and especially Indonesia (see table 1). The region's income distribution is typically characterized as relatively equitable. ${ }^{61}$ But, on average, income ine-

60. Analysts have considered a variety of additional policies, including financial market policy, infrastructure development, and the exchange rate regime.

61. Deininger and Squire (1996) report data for the income shares of the top relative to the bottom quintile in a variety of countries in various years. According to this 
quality in East Asia is similar to that in South Asia and in the Middle East. Malaysia, like the Philippines, has quite high income inequality, comparable to that in Latin America. Only Korea and Taiwan began with highly equitable income distributions; the others enjoyed rising equality along with rapid growth.

The seven countries are now frequently cited for high rates of investment and saving. However, most began with low to moderate investment and saving rates. Dramatic increases in saving rates, in particular, are a hallmark of their successful development. Similarly, exports initially represented a modest share of GDP, and very rapid export growth is another striking feature that these countries have in common.

There are also both similarities and differences in the policies pursued in the region. ${ }^{62}$ Overall, the East Asian countries have tended to follow prudent macroeconomic policies, as discussed further below. Average fiscal deficits have been low, thus limiting the need for inflationary finance. Public saving rates have been relatively high. Inflation rates have tended to be moderate (although not exceptionally low); real interest rates have been quite stable; and black market exchange rate premiums have been very small.

The broad averages mask considerable cross-country diversity. Budget deficits have not always been small, nor have inflation rates consistently been in single digits. In Thailand, the central government deficit ranged from 3.5 to 6.5 percent of GDP during the nine years from 1978 to 1986 . Malaysia's budget deficit reached 15.5 percent of GDP during 1981-82, and averaged 6.9 percent over 1960-92. Consumer price index inflation averaged 20 percent per year during 197481 in Korea, and reached as high as 40 percent per year in Indonesia in 1974. However, a key feature in all of these cases is that surges in budget deficits or inflation were reversed relatively quickly-govern-

indicator, the most equitable East Asian countries are Taiwan, China, and Indonesia, with ratios between 4.5 and 5.5. Korea and Singapore are somewhat less equitable, with ratios of 6.3 and 6.7. Least equitable are Thailand (11.7), the Philippines (12.0), and Malaysia (14.2). The regional averages are 7.2 for East Asia, 5.5 for South Asia, 7.1 for the Middle East, 11.6 for Africa, 16.0 for Latin America, and 6.6 among industrial economies.

62. For summaries of the range of policies pursued in each of the high-growth Asian countries, see World Bank (1993a) and its extensive references. 
ments adjusted policies promptly when indicators got far out of line. ${ }^{63}$ Consequently, economic crises in the high-performing East Asian countries appear to have been shorter and less severe than many of those experienced elsewhere. These countries do not show that moderate but persistent inflation or budget deficits are inconsistent with long periods of rapid growth, nor that there is any need to be preoccupied with doctrinaire targets, such as zero inflation, or budget surpluses; but, for the most part, they have avoided the extremes. In this regard, our reading of the East Asian experience in terms of macroeconomic policy and performance is similar to that of Stanley Fischer. ${ }^{64}$

The governments in the region promoted broad-based educational increases through the allocation, if not the level, of public spending. ${ }^{65}$ Government expenditures tended to be concentrated on the lower grades, particularly while literacy rates were low. Spending at the postsecondary level was limited and focused on strengthening technical skills. As shown above, the East Asian countries did achieve impressive increases in the educational attainment of their populations. At the same time, our accounting decomposition implies that the direct effect of increased schooling for growth was modest in East Asia, adding perhaps 0.2 and 0.4 percentage point relative to annual growth in Latin America and Africa, respectively (see table 7). However, these figures do not take into account the potentially significant positive implications for per capita growth rates as increased education contributes to lower population growth rates.

In the early 1960s trade policies in all of the East Asian economies (except Hong Kong) could be characterized as promoting import substitution, with strong biases against exports. Following Japan's example, each shifted away from this inward-looking development strategy toward an outward-oriented strategy based on promoting exports, especially manufactured goods. Korea, Singapore, and Taiwan made the switch during the mid- to late 1960s. Like Japan, however, Korea and Taiwan initially maintained significant protection of their domestic markets and promoted exports through a variety of selective measures, such as export credits and tax incentives; the move away from extensive

63. See, for example, Collins (1989).

64. See Fischer (1993).

65. Compared with other countries, government spending on education has been moderate in Taiwan, Singapore, and Korea. 
usage of selective measures is quite recent. Korea's "big push" to develop heavy and chemical industries during the 1970s stands out as an example of very intensive intervention. While Korean development has been associated with very large conglomerates, Taiwanese exporters are primarily small and medium-sized firms. Indonesia, Malaysia, and Thailand shifted to export promotion strategies in the early 1980s. Their approaches placed less emphasis on targeted intervention, but in all cases some selective measures were used to promote designated industries. Finally, all of the countries encouraged capital goods imports, licensing arrangements, and training abroad as means to transfer more efficient technologies from the industrial countries. Foreign direct investment, however, was welcomed in Malaysia and Singapore, and more recently in Indonesia and Thailand, but was heavily restricted in Taiwan and especially Korea.

\section{Regression Analysis}

The association between policies and growth is explored more formally through regression analysis. A new feature of our analysis is to use the components of growth-capital accumulation and changes in TFP - as dependent variables, which enables us to study the channels through which the various policies operate. Following the existing literature, we concentrate on macroeconomic policy and on outwardoriented trade policy.

Our choice of indicators of macroeconomic policy is heavily influenced by the prior studies of Barro, Lee, and Fischer ${ }^{66}$ In particular, we focus on the average budget balance as a share of GDP over the period 1960-92 as a broad measure of fiscal discipline and on the variability of the real exchange rate during 1960-92 as a measure of the stability of macroeconomic policy ${ }^{67}$ While fiscal data are available for all but one country in our sample (Sudan), they come from different sources, raising issues of comparability and quality. The measures of fiscal balance for industrial countries come from OECD statistical files and tend to be close to the standard national accounts concept of the

66. Barro (1991), Barro and Lee (1994b), and Fischer (1993).

67. In Bosworth, Collins, and Chen (1996) we consider other macroeconomic policy indicators, such as the average level and change in the real exchange rate, the average level and standard deviation of inflation, and the share of government consumption in GDP. 
general government sector. In most cases, data for developing economies come from the IMF's International Financial Statistics or World Bank studies and are based on the concept of the consolidated general government budget. In a few cases, data are based on the broader concept of the public sector budget.

The real exchange rate measure is based on the international price of consumption goods from the PWT; as such, it provides an indicator of under- or overvaluation of the currency, relative to purchasing power parity. There is, however, a general tendency for a country's relative price level to increase with income. Thus we follow the procedure developed by David Dollar to adjust our series for this systematic bias. ${ }^{68}$ The international price of consumption, converted to U.S. dollars using the standard exchange rate, is regressed on the ratio of per capita GDP for each country relative to that of the United States. Residuals from this regression are used as adjusted prices. Each country's real exchange rate is then its adjusted price level, relative to a sample average that is constructed using trade weights. We also include various measures of the level and stability of inflation. However, these are consistently insignificant in the regressions.

Alternative trade policy measures can be divided into three types. ${ }^{69}$ First, there are direct measures of tariff and nontariff barriers (NTBs). ${ }^{70}$ Second, there are those based on trade flows. Actual imports and exports will differ across countries because of country size, factor endowments, and other features that have nothing to do with policy stance. Thus it has become common to estimate a "gravity," or a structural, model of trade flows and to assume that the regression residuals reflect the underlying policy stance. ${ }^{71}$ Finally, a number of authors have constructed qualitative indexes of trade policy, based on a variety of un-

68. Dollar (1992).

69. See Bosworth, Collins, and Chen (1996) and the references therein for further discussion of this issue.

70. NTBs, arguably more important than tariff barriers in terms of industrial targeting, are notoriously difficult to measure. Furthermore, the comparable comprehensive figures (from the United Nations Conference on Trade and Development [UNCTAD]) are for the mid-1980s, not the early years of East Asia's economic take-off.

71. This procedure can be applied to total imports or to categories, such as imports of consumer versus capital goods. However, adjusted trade flow measures tend to have low correlations with direct trade policy measures and are likely to be endogenous. In any case, the association between adjusted trade shares and output growth does not appear to be robust. 
derlying indicators. These tend to enter growth regressions with large and very significant coefficients, compared with direct and trade flow measures. However, they may provide relatively poor proxies for trade policy, as discussed further below. Jeffrey Sachs and Andrew Warner have recently developed one such measure. They define a country as closed if any of the following five conditions applied during 1970-89, and open otherwise: (1) NTBs covering at least 40 percent of trade, (2) average tariff rates of at least 40 percent, (3) an average black market premium of at least 20 percent during the 1970s or the 1980s, (4) a socialist economic system, and (5) a state monopoly on major exports. ${ }^{72}$

While our previous work has employed all three types of trade policy measure, the present discussion focuses on the results based on the Sachs and Warner measure of openness, for two reasons. ${ }^{73}$ First, we wish to explore further the significance of measures that previous analyses have found to show the importance of outward-oriented trade policy as a determinant of growth. The arguably preferable direct and trade flow measures do not seem to be significantly related to growth performance. Our previous analysis finds that neither the tariff nor the NTB measures were significantly associated with growth or its components. We have found some evidence that an adjusted measure of capital goods imports as a share of GDP is associated with more rapid capital accumulation, but no evidence of any link with productivity growth. ${ }^{74} \mathrm{Sec}-$ ond, the Sachs-Warner index is available for eighty-three of the countries in our sample, whereas alternative indicators would have reduced our sample size much further. ${ }^{75}$

Table 11 provides a summary of the macroeconomic and trade policy indicators for individual East Asian countries and for the regional groupings. As shown, real exchange rates have been relatively stable in East Asia. The region is characterized by low average budget deficits, comparable to those among industrial countries, and less than half of

72. Sachs and Warner (1995).

73. Bosworth, Collins, and Chen (1996). In the present paper, our empirical analysis uses revised data obtained directly from Sachs and Warner.

74. Bosworth, Collins, and Chen (1996).

75. The eighty-three-country sample excludes Iceland, Malta, Panama, South Africa, and Sudan. An alternative qualitative indicator constructed by the World Bank (1987) produces results similar to those using the Sachs and Warner indicator. The results for direct and trade flow measures and the World Bank indicator are based on subsamples of our data. 


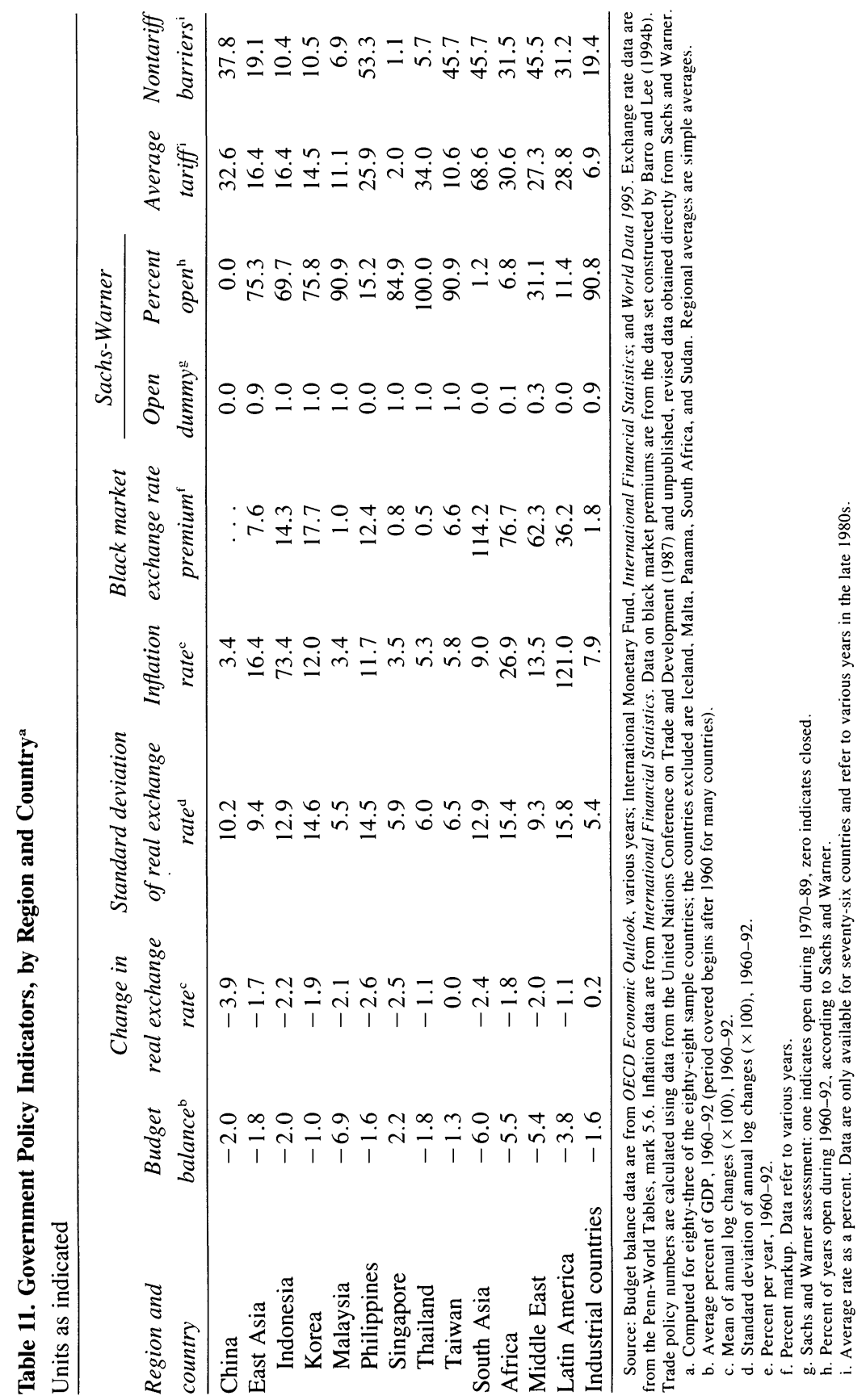


the level in Latin America, for example. Finally, East Asia stands out as extremely open, based on the openness indicator borrowed from Sachs and Warner. From the percentage of country years classified as open during 1960-92, East Asia (75 percent) is second only to the industrial economies (91 percent), and considerably more open than the Middle East (31 percent), the third most open region. In the other regions, few, if any, countries are classified as open over the entire period. This indicator is very successful in singling out the East Asian economies.

Regression results are reported in table $12 .{ }^{76}$ The role of macroeconomic policy is considered first. As shown, countries with smaller budget deficits and more stable real exchange rates tend to grow more rapidly. However, the two elements of policy work through very different channels. Budget surpluses are strongly associated with more rapid accumulation of capital per worker, while real exchange rate stability is associated with improved (or higher) productivity growth.

We find the Sachs-Warner index of years open to be strongly associated with growth. Sachs and Warner's interpretation is that an open trade policy is the most important element of overall economic policy: if and only if poorer countries are open will they tend to grow more rapidly than richer countries and to catch up. Further, they argue that the main reason to expect the convergence of open economies is that poorer countries can import capital and modern technology from wealthier ones, thereby reaping "the advantages of backwardness." 77 Our results create some difficulty for this interpretation because the variable adds nothing to the explanation of differences in productivity growth (see column 8). All of its influence comes through a positive effect on accumulation of capital per worker (see column 5). To the extent that the indicator is assumed to capture outward orientation, the lack of evidence that this policy stance is linked to the transfer of more efficient production techniques is striking.

However, the Sachs-Warner index, like other categorical indicators, may have little to say about the underlying trade policies. It places a heavy weight on the premium (discount) in the black market for foreign

76. These regressions are all based on a sample size of eighty-three. For comparative purposes, the regressions with initial and external conditions were run again for the eighty-three-country subsample, yielding only minor changes in the results.

77. Sachs and Warner (1995, p. 3). 


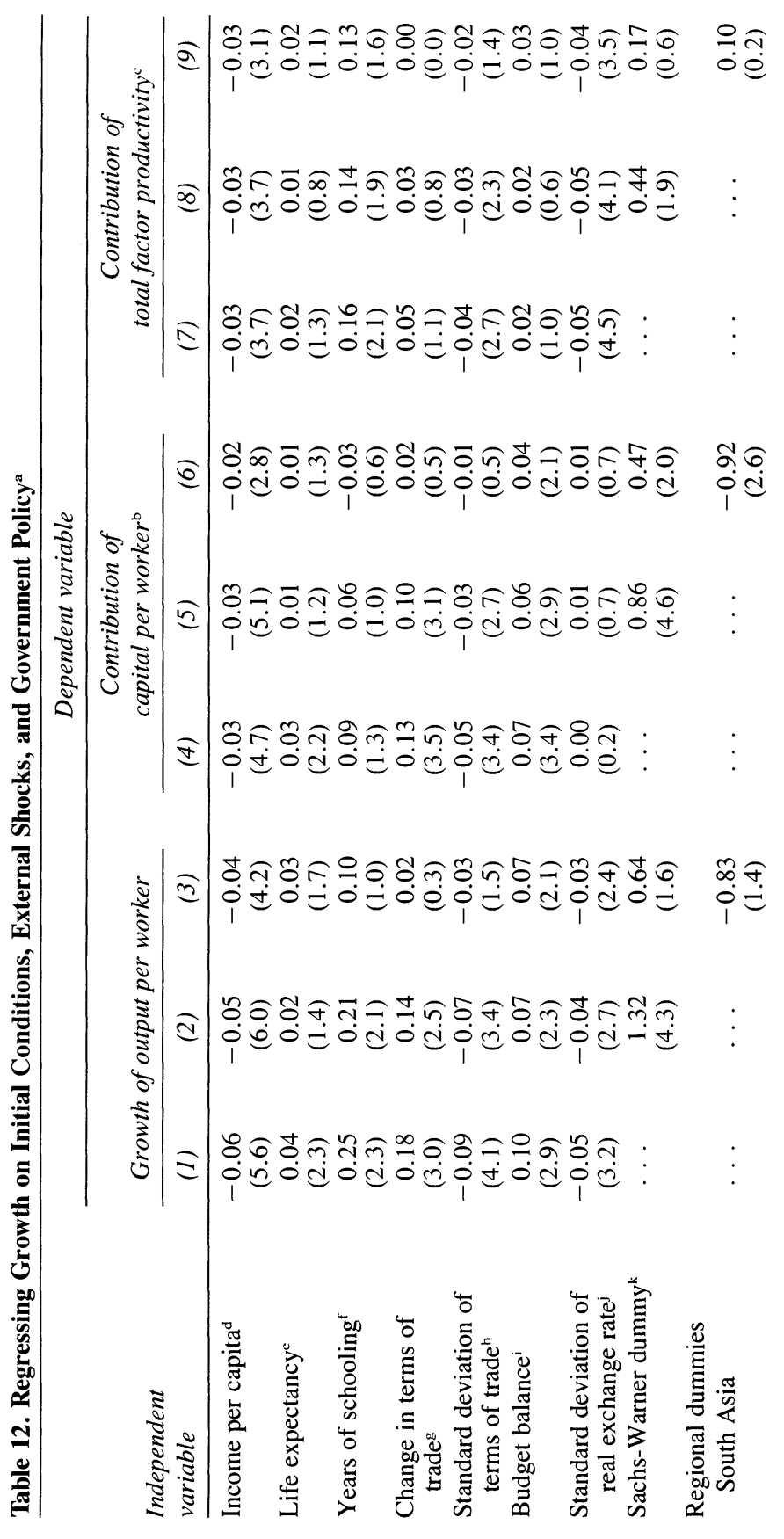




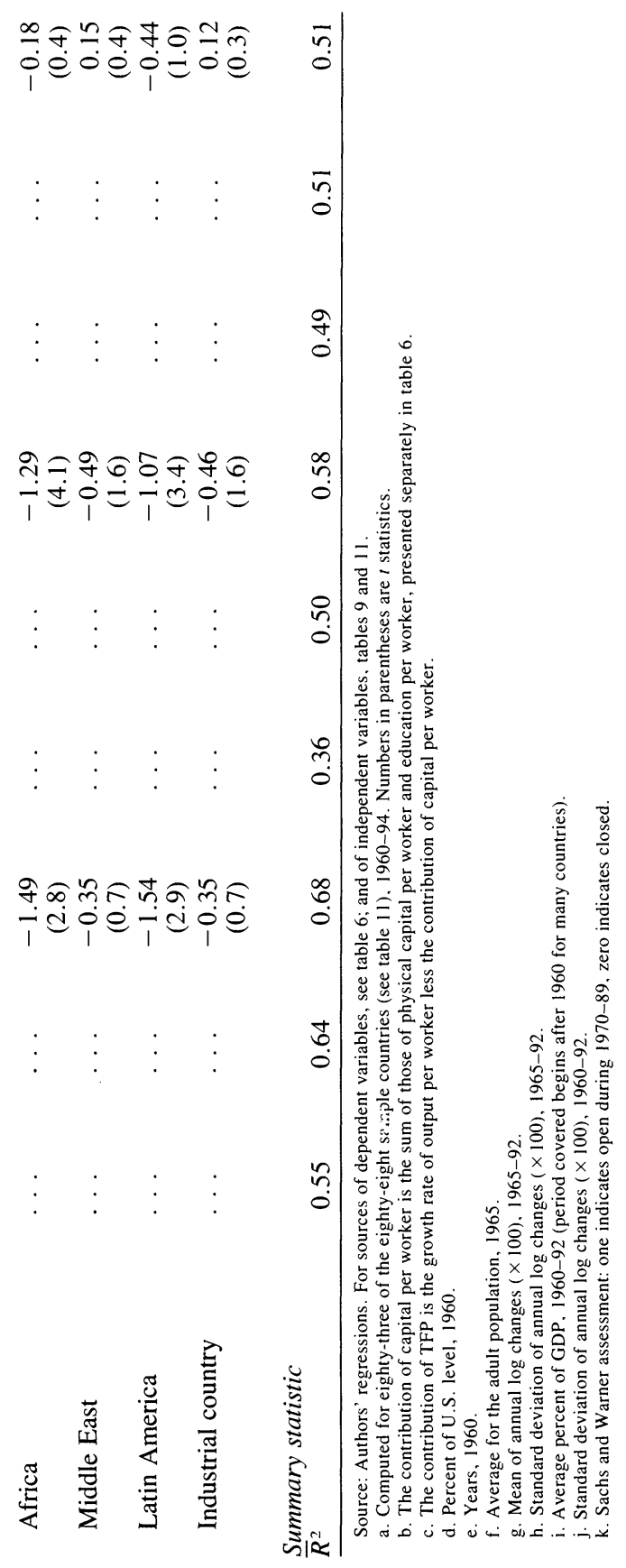


exchange. The black market premium is not a measure of trade policy, per se, but rather is likely to strongly reflect the general economic condition of a country. The reliance on the black market premium is also likely to make problems of endogeneity especially acute. More generally, the Sachs and Warner openness indicator is as strongly correlated with our macroeconomic policy indicators (budget surplus and real exchange rate stability) as with the direct trade policy measures (tariff and nontariff barriers). Finally, categorical measures force stark distinctions among countries, but it is unclear whether these really reflect underlying differences in trade policy. Such indicators do not capture underlying differences in the nature and extent of selective government interventions at the industry level.

We conclude that categorical indicators like the Sachs-Warner index do appear to be signficantly correlated with growth. But the channel of effectiveness is increasing capital accumulation, not productivity growth. Furthermore, problems with this measure imply that we cannot draw conclusions about the role of trade policies or selective intervention from these results. To do so would require measures that more accurately capture differences in trade policy.

Overall, the policy measures account for about one-third of the otherwise unexplained difference between growth performance in East Asia and other developing regions. That is, the size of the regional coefficients in column 3 of table 12 are about one-third smaller than the regional effects in column 2 of table 10 . Further, the reduction is evenly divided between capital accumulation and TFP growth.

\section{Concluding Thoughts}

Our examination of the data for East Asia produces several major questions. Two of these follow from the finding that East Asia is distinguished by the magnitude of capital accumulation, but that gains in productivity have been quite ordinary. First, why has TFP growth been so moderate, given the obvious opportunities to simply copy the technologies of the industrial economies? And second, what enabled the East Asian economies to achieve and maintain such high rates of capital accumulation? The third questions Krugman's provocative conclusion that if past growth was due to rapid capital accumulation, the law of 
diminishing returns would imply that East Asia's days of rapid growth are numbered. ${ }^{78}$ Is this assessment correct? Finally, the finding that TFP growth has played only a limited role casts doubt on the relevance of much of the new growth theory, which suggests that the transfer of ideas provides a less costly means of economic catchup than capital accumulation.

\section{Why Was TFP Growth So Modest?}

Previous growth accounting studies have found large contributions from TFP for industrial countries that enjoyed periods of rapid output growth. ${ }^{79} \mathrm{We}$ find similar TFP contributions for industrial countries in the earliest period of our sample. Table 7 shows that the average contribution of TFP to growth of output per worker during 1960-73 was 2.1 percentage points among all non-U.S. industrial countries-more than twice its contribution ( 0.9 percentage points) in the United States. Six of the seven industrial countries with the highest growth had annual contributions of TFP to output growth of at least 2.6 percentage points ${ }^{80} \mathrm{~A}$ common explanation for these large TFP contributions has been that other industrial countries were catching up with the technical expertise of the United States. Why did East Asia not have a similar experience? Much of the East Asian growth occurred after 1973, when TFP gains were smaller throughout the industrial economies; but given the magnitude of the technology gap, it is difficult to see why developments at the frontier were of relevance to East Asia. To varying degrees, the East Asian economies followed Japan in pursuing a development strategy that involved sequenced promotion of low, middle,

78. Krugman (1994).

79. For example, Denison and Chung (1976) find that TFP growth contributed from 1.9 to 4.9 percentage points per year to growth for nine industrial countries (those with at least 3 percent annual average growth) over various periods between 1948 and 1971 . Christenson, Cummings, and Jorgenson (1980) find that the contribution of TFP to growth for eight industrial countries over selected periods within 1947-73 ranged from 1.4 to 4.1 percentage points per year. For a variety of reasons, these TFP estimates are not strictly comparable to ours, which helps to explain their magnitudes. In particular, Denison's estimates apply to net, not gross, output.

80. These countries (with annual percentage point contributions from productivity growth during 1960-73 in parentheses) are Greece (3.6), Italy (2.6), Japan (3.3), Portugal (3.8), Spain (3.3), and Turkey (2.6). The contribution of TFP growth in Austria was 1.9 percentage points per year. In all of these countries, the annual growth rate of output per worker was at least 4.8 percent. 
and high technology industries. But unlike Japan in the 1960s, their increases in TFP have been modest.

It is possible that the potential to adopt knowledge and technology from abroad depends on a country's stage of development. ${ }^{81}$ Growth in the early stages may be primarily associated with physical and human capital accumulation, and significant potential for growth through catchup may only emerge once a country has crossed some developmental threshold. Gene Grossman and Elhanan Helpman may be correct in arguing that even if "technological progress provides the engine of long-run growth, accumulation will play an independent role during a (perhaps prolonged) transitional phase." 82

To explore this hypothesis of stages of growth, we compare development indicators for the East Asian countries in 1975 with indicators in 1965 for the six industrial countries with the highest TFP growth rates during 1960-73. The Asian countries were indeed less developed than their high-growth industrial counterparts. On average, the industrial countries had more than a year of additional schooling, as well more than three times the amount of capital per worker. Less than a third of their labor force was employed in agriculture, compared with nearly half for the Asian countries. While these comparisons do not provide a formal test, they are consistent with the view that the low TFP growth in East Asia during 1960-94 (or 1973-94) relative to that in high-growth industrial economies during the 1960s is due in part to the Asian economies' being at an earlier stage of development. Also consistent with the stages of development hypothesis is that TFP growth accelerated sharply after 1984 in many of these countries.

\section{High Capital Accumulation}

The East Asian economies are most remarkable for the magnitude of their capital accumulation. An important implication of the analysis

81. The idea that countries pass through different stages of development, and that to embark on a stage in which growth is characterized by significant technological improvements might require certain preconditions, was widely discussed in the early economic development literature; see, for example, Rostow (1960). Recent studies have used modern analytic tools to revisit the potential importance of developmental stages. For example, Azariadis and Drazen (1990) develop a model of economic growth in which returns to scale rise rapidly once economic characteristics such as labor quality reach a critical range.

82. Grossman and Helpman (1994, p. 26). 
above is that this impressive achievement should be the focus of future work that seeks to draw lessons from the region's rapid growth. In this context, it is useful to highlight the key features of the experience.

Figure 4 shows the historical pattern of saving and investment as a percentage of GDP for the six high performing countries. While there are obvious differences among them, there are also some common features. First, rates of national saving rose throughout the period of accelerating growth, providing a striking example of a virtuous circle in which rising rates of capital formation and growth fed on one another. Indonesia, Korea, and Singapore began with relatively low rates of saving (as did Taiwan, in the 1950s). The data certainly do not support the hypothesis that high saving in East Asia is due to some cultural predisposition. The great expansion of saving in Singapore was the result of a program of mandated saving, and the surge in saving in Thailand in the late 1980s was concentrated in the public sector. But for the other countries, it is difficult to relate the pattern of rising saving directly to any specific government policies. Most of these governments have followed very conservative financial market policies, emphasizing the avoidance of crises and generally maintaining positive real interest rates. Furthermore, open bond and equity markets have played a relatively minor role in the financing of investment, relative to institutional lending.

In addition, several of the countries depended heavily on foreign capital inflows to finance the initial surge of investment. For Korea, the capital inflow averaged 6 percent of GDP throughout the 1960s and 1970s. Singapore relied even more on capital inflows, until the mid1980s. More recently, both Singapore and Taiwan have experienced a significant falloff in domestic investment, and they are now generating large capital outflows.

\section{The Outlook for Future Growth}

Krugman, among others, has suggested that East Asia's growth must slow in the future because of what he characterizes as an excessive reliance on capital formation. Over time, a rapid rate of growth in the capital stock-a rate well in excess of growth in output - should push down the return to capital and ultimately divert investment to other regions. And it is true that figure 4 shows the investment rate slowing 
Figure 4. Saving-Investment Balance, Selected East Asian Countries

Percent of GDP
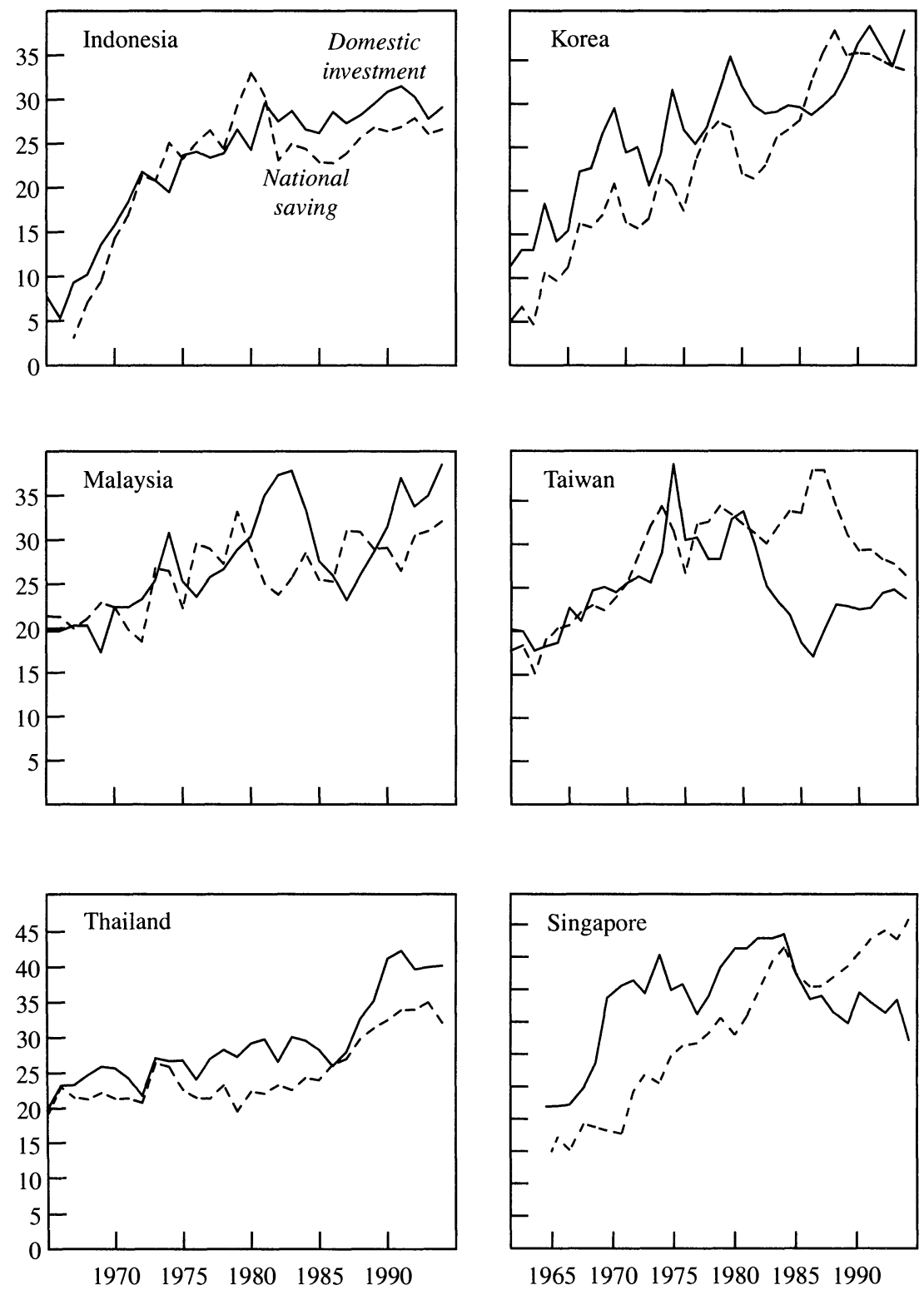

Source: World Data 1995. 
Table 13. Output and Capital per Worker, Selected Countries, 1970 and 1994 Index, United States $1970=100$, except as indicated

\begin{tabular}{|c|c|c|c|c|c|c|c|c|}
\hline \multirow[b]{2}{*}{ Country } & \multicolumn{2}{|c|}{$\begin{array}{l}\text { Output per } \\
\text { worker }\end{array}$} & \multicolumn{2}{|c|}{$\begin{array}{c}\text { Physical } \\
\text { capital per } \\
\text { worker }\end{array}$} & \multicolumn{2}{|c|}{$\begin{array}{c}\text { Education per } \\
\text { worker }^{\mathrm{a}}\end{array}$} & \multicolumn{2}{|c|}{$\begin{array}{l}\text { Capital-to- } \\
\text { output ratio }^{\mathrm{b}}\end{array}$} \\
\hline & 1970 & 1994 & 1970 & 1994 & 1970 & 1994 & 1970 & 1994 \\
\hline China & 3.2 & 10.4 & 1.5 & 6.6 & 56.4 & 65.3 & 1.5 & 1.7 \\
\hline Indonesia & 6.8 & 15.1 & 2.5 & 16.2 & 58.0 & 69.0 & 1.2 & 2.8 \\
\hline Korea & 13.2 & 52.9 & 5.0 & 49.4 & 74.3 & 95.3 & 1.2 & 2.9 \\
\hline Malaysia & 18.9 & 46.8 & 8.1 & 37.8 & 63.1 & 77.2 & 1.3 & 2.5 \\
\hline Philippines & 10.9 & 13.4 & 4.1 & 8.5 & 73.3 & 88.3 & 1.2 & 2.0 \\
\hline Singapore & 30.0 & 77.3 & 13.0 & 72.5 & 65.2 & 74.9 & 1.4 & 2.9 \\
\hline Thailand & 8.4 & 26.7 & 3.0 & 15.2 & 61.4 & 76.4 & 1.1 & 1.8 \\
\hline Taiwan & 18.5 & 67.7 & 7.2 & 47.6 & 68.9 & 87.9 & 1.2 & 2.2 \\
\hline Japan & 44.0 & 85.5 & 30.9 & 124.9 & 79.8 & 92.7 & 2.2 & 4.6 \\
\hline United States & 100.0 & 118.5 & 100.0 & 122.5 & 100.0 & 110.2 & 3.1 & 3.2 \\
\hline
\end{tabular}

Source: Authors' calculations using data sources for table 6. Numbers are converted to U.S. dollars by using purchasing power parity exchange rates for 1970 from the Penn-World Tables, mark 5.6

a. Indexed level of the labor quality measure, $H$.

b. Actual ratio.

in Singapore and Taiwan. Yet the other countries continue to be highly popular destinations for foreign capital, and recent experience does not seem to support any notion of a major slowing of growth.

To examine the outlook for East Asia, we construct measures of income and capital per worker, using international price data ${ }^{83}$ Key aspects are summarized in table 13. These figures show that despite the rapidity of the past growth, most of these countries still have a considerable distance to go before they reach levels of output per worker comparable to those in the United States. Furthermore, their stocks of physical capital per worker are still quite low-generally less than half of those of the United States and Japan.

Krugman is certainly right to say that these countries cannot continue to assume that capital per worker will expand in excess of the growth in labor-augmenting technical change, without significant reductions in the return to capital. However, it is important to incorporate two offsetting factors, each of which provides grounds for optimism. First, the quality-weighted labor force will continue to expand as a consequence

83. The use of international price data, drawn from the latest version of the PWT, makes comparison possible across countries. However, even the estimates from comparable international prices are subject to substantial uncertainty. 
of improvements in average education levels. Even though the levels of education of young age cohorts in these countries are comparable to their counterparts in the United States and Japan, the passage of time alone will raise the average educational level as older, less educated workers leave the labor force. On the basis of our simple index, labor quality in these countries is still 20 to 30 percent below that of the United States. A second factor is the apparent improvement in TFP growth over the past decade, particularly in Korea, Singapore, Thailand, and Taiwan (see table 7). Our data suggest that these countries have hardly exhausted the potential for catching up.

As table 13 shows, all of these countries have experienced a major rise in the capital-to-output ratio, which would be expected to have driven down the return to capital. Korea and Singapore, for example, now have capital-to-output ratios comparable to that of the United States, suggesting that they may face significant limits on future capital accumulation without commensurate increases in TFP; but for both countries, the ratios are still well short of Japan's. Most of the other countries, however, have capital-to-output ratios that imply considerable capacity for further capital deepening. In sum, there appears to be room for high growth to continue in East Asia before the countries of this region converge to the performance levels that characterize the industrial economies. 


\section{Country Sample}

THE EIGHTY-EIGHT countries in our sample, in their regional groupings, are as follows:

\begin{tabular}{|c|c|c|}
\hline China & Middle East & $\begin{array}{l}\text { Industrial countries } \\
\text { Australia }\end{array}$ \\
\hline East Asia & $\begin{array}{l}\text { (with North Africa) } \\
\text { Algeria }\end{array}$ & $\begin{array}{l}\text { Australia } \\
\text { Austria }\end{array}$ \\
\hline Indonesia & Cyprus & Belgium \\
\hline $\begin{array}{l}\text { Korea } \\
\text { Malaysia }\end{array}$ & Egypt & Canada \\
\hline $\begin{array}{l}\text { Malaysia } \\
\text { Philippines }\end{array}$ & Iran & Denmark \\
\hline $\begin{array}{l}\text { Philippines } \\
\text { Singapore }\end{array}$ & Israel & Finland \\
\hline $\begin{array}{l}\text { Singapore } \\
\text { Taiwan }\end{array}$ & Jordan & France \\
\hline Thailand & Malta & Germany \\
\hline South Asia & $\begin{array}{l}\text { Morocco } \\
\text { Tunisia }\end{array}$ & $\begin{array}{l}\text { Greece } \\
\text { Iceland }\end{array}$ \\
\hline $\begin{array}{l}\text { Bangladesh } \\
\text { India }\end{array}$ & Latin America & Ireland \\
\hline $\begin{array}{l}\text { India } \\
\text { Myanmar }\end{array}$ & Argentina & Italy \\
\hline $\begin{array}{l}\text { Myanmar } \\
\text { Pakistan }\end{array}$ & Bolivia & Japan \\
\hline $\begin{array}{l}\text { Pakistan } \\
\text { Sri Lanka }\end{array}$ & Brazil & Netherlands \\
\hline $\begin{array}{l}\text { Sri Lanka } \\
\text { Africa (sub-Saharan) }\end{array}$ & Chile & New Zealand \\
\hline $\begin{array}{l}\text { Africa (sub-Saharan) } \\
\text { Cameroon }\end{array}$ & Columbia & Norway \\
\hline $\begin{array}{l}\text { Cameroon } \\
\text { Cote d'Ivoire }\end{array}$ & Costa Rica & Portugal \\
\hline $\begin{array}{l}\text { Cote d'Ivoire } \\
\text { Ethiopia }\end{array}$ & Dominican Republic & Spain \\
\hline $\begin{array}{l}\text { Ethiopia } \\
\text { Ghana }\end{array}$ & Ecuador & Sweden \\
\hline Ghana & El Salvador & \\
\hline Kenya & Guatemala & $\begin{array}{l}\text { Turkey } \\
\text { United Kingdom }\end{array}$ \\
\hline Madagascar & Guyana & \\
\hline Malawi & Haiti & \\
\hline Mali & Honduras & \\
\hline Mauritius & Jamaica & \\
\hline Mozambique & Mexico & \\
\hline Nigeria & Nicaragua & \\
\hline Rwanda & Panama & \\
\hline Senegal & Paraguay & \\
\hline Sierra Leone & Peru & \\
\hline South Africa & Trinidad and Tobago & \\
\hline Sudan & Uruguay & \\
\hline Tanzania & Venezuela & \\
\hline Uganda & & \\
\hline Zaire & & \\
\hline Zambia & & \\
\hline Zimbabwe & & \\
\hline
\end{tabular}




\section{Comments}

Dani Rodrik: It is a rare treat to read a serious paper on East Asia that does not have an axe to grind. The present study deserves credit on these grounds alone. Collins and Bosworth have done a nice job of amassing new evidence on the sources of growth for a broad crosssection of countries. And their interpretation of the evidence is balanced and judicious. My main disappointment is that they do not take the logic of their findings far enough, and therefore leave the reader with something less than a complete story.

I make three broad points here. The first concerns the shortcomings of the authors' TFP growth calculations; the second is about how to squeeze additional information out of the cross-country regressions; and the third concerns the role of government policy in stimulating private investment.

What Do the TFP Growth Calculations Really Show? Along with all the other researchers who have undertaken careful analyses of the sources of growth, Collins and Bosworth find that East Asia presents a miracle of accumulation (of physical capital, in particular) rather than of productivity. However, the evidence on this issue is less clear-cut than would seem at first sight. While the evidence on investment rates is direct and speaks for itself, the evidence on TFP is indirect and has to be intrepreted with care. A general theorem derived by Peter Diamond, Daniel McFadden, and Miguel Rodriguez says that it is impossible to disentangle factor-augmenting technological change from the shape of the production function (and, in particular, from its elasticity of substitution). ${ }^{1}$ In the present context, this implies that researchers

1. Diamond, McFadden, and Rodriguez (1978).

192 
Table B1. Total Factor Productivity Growth Rates and Capital Shares Implied by Alternative Assumptions about Factor Substitution, East Asia ${ }^{a}$

Units as indicated

\begin{tabular}{|c|c|c|c|c|c|c|}
\hline \multirow[b]{2}{*}{$\begin{array}{l}\text { Elasticity of } \\
\text { substitution }\end{array}$} & \multicolumn{3}{|c|}{$\begin{array}{l}\text { Implied total factor productivity } \\
\text { growth }\end{array}$} & \multicolumn{3}{|c|}{ Implied capital share ${ }^{\mathrm{c}}$} \\
\hline & $\begin{array}{l}\text { After } 10 \\
\text { years }\end{array}$ & $\begin{array}{l}\text { After } 20 \\
\text { years }\end{array}$ & $\begin{array}{l}\text { After } 30 \\
\text { years }\end{array}$ & $\begin{array}{l}\text { After } 10 \\
\text { years }\end{array}$ & $\begin{array}{c}\text { After } 20 \\
\text { years }\end{array}$ & $\begin{array}{c}\text { After } 30 \\
\text { years }\end{array}$ \\
\hline 1.0 & 1.03 & 1.03 & 1.03 & 0.35 & 0.35 & 0.35 \\
\hline 0.9 & 1.14 & 1.25 & 1.36 & 0.33 & 0.32 & 0.30 \\
\hline 0.8 & 1.28 & 1.51 & 1.73 & 0.31 & 0.28 & 0.24 \\
\hline 0.7 & 1.44 & 1.81 & 2.13 & 0.29 & 0.23 & 0.18 \\
\hline 0.6 & 1.66 & 2.16 & 2.53 & 0.25 & 0.18 & 0.12 \\
\hline 0.5 & 1.93 & 2.53 & 2.89 & 0.21 & 0.12 & 0.06 \\
\hline 0.4 & 2.27 & 2.89 & 3.15 & 0.16 & 0.06 & 0.02 \\
\hline 0.3 & 2.68 & 3.17 & 3.27 & 0.10 & 0.02 & 0.00 \\
\hline 0.2 & 3.09 & 3.29 & 3.30 & 0.03 & 0.00 & 0.00 \\
\hline 0.1 & 3.29 & 3.30 & 3.30 & 0.00 & 0.00 & 0.00 \\
\hline
\end{tabular}

Source: Author's calculations based on output and factor accumulation data provided by Collins and Bosworth

a. Calculated for the sample of countries compiled by Collins and Bosworth (see appendix A to their paper in this volume), using input and output growth rates for the period 1960-94. Calculations assume an initial capital share of 0.35 .

b. Annual percentage rate as calculated after given number of years and assuming given elasticity of substitution

c. Calculated using equation $\mathrm{B} 1$.

may be misattributing labor-augmenting technical change in East Asia to an assumed elasticity of substitution that is too high, with the consequence that TFP growth is underestimated.

To see how this might happen, and how serious the implications are, here is a small exercise based on the Collins-Bosworth calculations for rates of factor accumulation. The authors assume that the production functions are of the Cobb-Douglas form, with a capital share $(\alpha)$ of 0.35 . This imposes an elasticity of substitution between capital and labor (including skills) of unity. Suppose, instead, that the true elasticity of substitution is below unity. Then capital deepening would cause the factor share of capital to fall over time (but see below). For given rates of capital deepening and output growth, the residual output growth attributed to TFP growth would increase correspondingly. This effect would be particularly strong in the East Asian countries, as they have experienced the greatest capital deepening.

Table B1 shows the magnitudes involved. Collins and Bosworth calculate an annual TFP growth rate of slightly over 1 percent per year for East Asia, over the period 1960-94. This is shown in the first row of table B1. The remaining rows display the implied TFP growth rates 
under different assumptions about the elasticity of substitution. For example, with an elasticity of substitution of 0.5 , the implied TFP growth rate would rise to 1.93 percent in ten years, 2.53 percent in twenty years, and 2.89 percent in thirty years. Clearly, the lower one's priors about the elasticity of substitution, the higher one must presume TFP growth rates to have been in East Asia.

One defense of the unitary elasticity of substitution might be that one does not actually observe the reductions in the capital share that would be implied by low elasticities of substitution (as displayed in table B1). ${ }^{2}$ But this is misleading because of the indeterminacy noted above. This indeterminacy has to do with the fact that a reduction in the marginal productivity of capital can be cushioned either by a high elasticity of substitution or by labor-augmenting technical change. My calculations have assumed that TFP growth is unbiased. Suppose, instead, that it was labor-augmenting; that is, that it favored the marginal productivity of capital. In that case, one would not have observed any significant decline in the capital share.

Formally, the rate of change of the capital share can be expressed as

$$
\hat{\alpha}=\frac{1-\sigma}{\sigma}(1-\alpha)\left[\hat{a}_{L}-\hat{k}\right],
$$

where $\sigma$ is the elasticity of substitution, $a_{L}$ is the labor-augmentation factor, $k$ is the capital-to-labor ratio, and hats denote percentage changes. As the equation shows, there is an observational equivalence between labor-augmenting technical change $\left(\hat{a}_{L}\right)$ and a $\sigma$ close to unity. The capital share $(\alpha)$ can remain constant for either reason, and one cannot distinguish empirically which one is the cause. ${ }^{3}$ Therefore one would have to place very strong priors on the likelihood that $\sigma$ is equal to one, or on the neutrality of technical change, in order to be able to rule out a significant amount of labor-augmenting technical change.

Cross-Country Regressions. Collins and Bosworth are right to stress the importance of macroeconomics-conservative fiscal policies and

2. The evidence on this point is not so clear cut either. It appears that profit rates and profit shares in Korean manufacturing have fallen substantially since the 1970s. Singh (1996, table 15) reports that the gross profit share in Korean manufacturing fell from 46 percent in 1975 to 33 percent in 1990.

3. See also Nelson and Pack (1995), who argue, in the East Asian context, that the strong diminishing returns to capital that would otherwise have followed were offset by technical advance. 
Table B2. Regressing Growth on Alternative Indicators of Government Policy, East Asia ${ }^{a}$

\begin{tabular}{|c|c|c|c|}
\hline Independent variable & (1) & $(2)$ & (3) \\
\hline Per capita income ${ }^{b}$ & $-0.05^{*}$ & $-0.06^{*}$ & $-0.05^{*}$ \\
\hline Life expectancy ${ }^{c}$ & 0.03 & 0.02 & 0.02 \\
\hline Years of schooling ${ }^{\mathrm{d}}$ & 0.11 & 0.04 & . . \\
\hline Change in terms of trade ${ }^{c}$ & 0.01 & -0.09 & -0.07 \\
\hline Standard deviation of terms of trade ${ }^{f}$ & -0.03 & 0.02 & 0.01 \\
\hline Budget balanceg & $0.07 \dagger$ & 0.05 & $0.06 \dagger$ \\
\hline $\begin{array}{l}\text { Standard deviation of real exchange } \\
\text { rate }\end{array}$ & $-0.03 \dagger$ & 0.00 & 0.00 \\
\hline Sachs-Warner dummy ${ }^{i}$ & $0.58 \dagger$ & 0.12 & \\
\hline Black market premium & $\ldots$ & $-0.66^{*}$ & $-0.72 *$ \\
\hline Institutional quality ${ }^{j}$ & $\ldots$ & $0.41^{*}$ & $0.41 *$ \\
\hline Schooling/initial income & $\cdots$ & $\cdots$ & $1.85 \dagger$ \\
\hline $\begin{array}{l}\text { Summary statistic } \\
\bar{R}^{2}\end{array}$ & 0.68 & 0.79 & 0.80 \\
\hline
\end{tabular}

Source: Author's regressions, as described in text. Data on institutional quality are from Knack and Keefer (1995). Data on openness are from Sachs and Warner (1995), but differ slightly from those used by Collins and Bosworth in this volume. Data on all other variables were provided by Collins and Bosworth; for sources, see table 11 of their paper in this volume.

a. The dependent variable is the growth rate of output per worker. The country sample differs slightly from that used by

Collins and Bosworth in their tables 11 and 12. The sample period is 1960-94. All regressions include regional dummies.

$*$ indicates significance at the 5 percent level; $\dagger$ indicates significance at the 1 percent level.

b. Percent of U.S. level, 1960.

c. Years, 1960

d. Average for the adult population, 1965.

e. Mean of annual log changes $(\times 100), 1965-92$.

f. Standard deviation of annual $\log$ changes $(\times 100), 1965-92$.

g. Average percent of GDP, 1960-92 (period covered begins after 1960 for many countries).

h. Standard deviation of annual log changes $(\times 100), 1960-92$.

i. Sachs and Warner assessment: one indicates open during 1970-89, zero indicates closed.

j. Knack and Keefer index: 1 indicates worst, 10 indicates best.

equilibrium exchange rates, in particular-in East Asia's success. This is probably the only noncontroversial lesson from the region. But I think that they could have teased more out of the regressions.

The regressions in table B2 make two points. First, institutions matter. One respect in which East Asia has stood out among developing regions is the quality of its bureaucracy. An index of the quality of governmental institutions (encompassing measures of the security of property and contractual rights and of bureaucratic quality) enters very significantly in the regressions (columns 2 and 3). ${ }^{4}$ Since the index ranges from 1 to 10 , the estimated coefficient indicates quite a strong effect from institutional quality: a difference of almost 4 percentage points in growth per worker between the worst institution and the best.

4. Knack and Keefer (1995). The index is constructed using original data from the International Country Risk Guide. 
Second, East Asia is special for having had a skilled work force relative to its capital stock in the early stages of development. This raised the return to capital and would account for the faster rates of capital accumulation. I use the ratio of initial schooling to initial income as a proxy for the gap between labor quality and physical capital. The value of this measure for East Asia is twice that for the rest of the world. Even though schooling does not enter significantly in the regressions on its own, it does become significant when normalized by income (column 3).

Hence these regressions provide a fuller picture of the cross-country evidence, emphasizing the importance of fiscal and exchange rate policies, bureaucratic institutions, and labor skills (relative to income).

Government Policy and Investment. The regressions in table B2 leave unexplained a 1 to 1.5 percentage point differential of growth per worker in East Asia relative to Latin America and Africa. Therefore it is necessary to complement the statistical work with a more detailed look at the individual experiences of these countries. Since capital accumulation is such an important part of the picture (even if laboraugmenting technical progress has been underestimated), one must ask what could have triggered the rise in the private return to capital that, in turn, induced a rise in the investment-to-GDP ratio of 20 percentage points in Korea, Taiwan, and Malaysia between the early 1960s and early 1980 s, and of 15 percentage points in Thailand in less than a decade since the mid-1980s.

Answering this question requires more of a case study (or perhaps event study) approach. My conjecture, based at least on the Korean and Taiwanese experiences, is that governments were heavily implicated in many of these leaps to high-investment equilibria. In both Korea and Taiwan, it is clear that the governments single-mindedly pursued investment and growth (from 1960 in Taiwan and from the early 1960s in Korea). In support of these goals, they deployed a wide range of policies, including administrative guidance, credit subsidies, tax incentives, public enterprises (to produce the intermediates needed by private industry downstream), tariff protection, and the socialization of investment risk. Any story about the transformation of these economies would be seriously incomplete without these elements.

At the other extreme, it is worth pondering why Hong Kong is the only country in the region that has not experienced a rise in its ratio of 
investment to GDP. As a reasonable first guess, this might be because Hong Kong's government has pursued a laissez-faire approach to economic policy and, unlike the others, has never developed an investment srategy. This is further evidence that activist government policies had a part in the other countries' leaps from low-investment to high-investment equilibria.

Barry P. Bosworth: Rodrick suggests that a constant capital share, in the face of substantial capital deepening, could result from either an elasticity of factor substitution equal to unity or, alternatively, an elasticity of substitution well below unity but offset by a high rate of laboraugmenting technical change. While these two situations imply quite different production functions, our results are little different in either case. Our decomposition of output growth between capital accumulation and TFP depends on the stability of capital's share, not on the elasticity of substitution. If the constancy is the result of a low degree of substitution and labor-augmenting technical change, the contribution of capital is not missed by our methodology: in the context of a Divisia index, capital's share of income is still the correct measure of its role, and the technology gains still show up as an increase in TFP. Rodrick is right, however, that the importance of technical change in preventing what would otherwise be a major erosion of capital's contribution is not sufficiently highlighted. Furthermore, the intepretation of the technical change term would be different if it were labor augmenting, because it would equal the residual divided by labor's share.

Is it possible that labor-augmented technical change could have maintained balance between the growth in the stock of capital and the effective labor supply? Over the period 1960-94, the increase in the capital-to-labor ratio ranged from seven-fold in Indonesia to more than twenty-fold in Korea, Singapore, and Taiwan. A rate of labor-augmenting technical change of equivalent magnitude, even when reduced by labor's share, would have implied increases in the computed TFP growth rates far in excess of those that we find. The assumption of a constant capital share is obviously important to our conclusions; but it is consistent with the finding of stable shares for the industrial countries in the presence of similar variations in the rate of capital accumulation; and Young finds little or no evidence of a decline in capital's share for Korea or Taiwan. 


\section{References}

Amsden, Alice H. 1989. Asia's Next Giant: South Korea and Late Industrialization. New York: Oxford University Press.

. 1991. "Diffusion of Development: The Late-Industrializing Model and Greater East Asia.' American Economic Review, Papers and Proceedings 81(2): 282-86.

1994. "Why Isn't the Whole World Experimenting with the East Asian Model to Develop? Review of The East Asian Miracle. "World Development 22(4): 627-33.

Azariadis, Costas, and Allan Drazen. 1990. "Threshold Externalities in Economic Development." Quarterly Journal of Economics 105(2): 501-26.

Barro, Robert J. 1991. "Economic Growth in a Cross Section of Countries.", Quarterly Journal of Economics 106(2): 407-43.

Barro, Robert J., and Jong-Wha Lee. 1994a. "International Comparisons of Educational Attainment.' Journal of Monetary Economics 32(3): 363-94.

1994b. "Sources of Economic Growth." Carnegie-Rochester Conference Series on Public Policy 40: 1-46.

Barro, Robert J., and Xavier Sala-i-Martin. 1992. "Convergence." Journal of Political Economy 100(2): 223-51.

1995. Economic Growth. New York: McGraw-Hill.

Baumol, William J., Richard R. Nelson, and Edward N. Wolff, editors. 1994. Convergence of Productivity: Cross-National Studies and Historical Evidence. New York: Oxford University Press.

Behrman, Jere R., and Mark R. Rosenzweig. 1994. "Caveat Emptor: CrossCountry Data on Education and the Labor Force.' Journal of Development Economics 44(1): 147-71.

Bell, Martin, and Keith Pavitt. 1992. “Accumulating Technological Capability in Developing Countries.' In Proceedings of the World Bank Annual Conference on Development Economics, edited by Lawrence H. Summers and Shekhar Shah. Washington: World Bank.

Benhabib, Jess, and Mark M. Spiegel. 1994. "The Role of Human Capital in Economic Development: Evidence from Aggregate Cross-Country Data." Journal of Monetary Economics 34(2): 143-73.

Bosworth, Barry P., Susan M. Collins, and Yu-chin Chen. 1996. "Accounting for Differences in Economic Growth.' In Structural Adjustment and Economic Reform: East Asia, Latin America, and Central and Eastern Europe, edited by Akira Kohsaka and Koichi Ohno. Tokyo: Institute of Developing Economies.

Card, David, and Alan B. Krueger. 1996. "Labor Market Effects of School Quality: Theory and Evidence.' In Does Money Matter? The Effect of School 
Resources on Student Achievement and Adult Success, edited by Gary Burtless. Washington: Brookings.

Christensen, Laurits R., Dianne Cummings, and Dale W. Jorgenson. 1980. “Economic Growth, 1947-73: An International Comparison." In New Developments in Productivity Measurement and Analysis, edited by John W. Kendrick and Beatrice N. Vaccara. Chicago: University of Chicago Press.

Collins, Susan M. 1989. "Debt, Policy and Performance: An Introduction." In Developing Country Debt and Economic Performance: Volume 3: Country Studies: Indonesia, Korea, Philippines, Turkey, edited by Jeffrey D. Sachs and Susan M. Collins. Chicago: University of Chicago Press and National Bureau of Economic Research.

Deininger, Klaus, and Lyn Squire. 1996. "Measuring Income Inequality: A New Data-Base."' Development Discussion Paper 537. Cambridge, Mass.: Harvard Institute for International Development (May).

Denison, Edward F. 1967. Why Growth Rates Differ: Postwar Experiences in Nine Western Countries. Washington: Brookings.

Denison, Edward F., and William K. Chung. 1976. How Japan's Economy Grew So Fast: The Sources of Postwar Expansion. Washington: Brookings.

Diamond, Peter, Daniel McFadden, and Miguel Rodriguez. 1978. "Measurement of the Elasticity of Factor Substitution and Bias of Technical Change.", In Production Economics: A Dual Approach to Theory and Applications, vol. 2, edited by Melvyn Fuss and Daniel McFadden. New York: NorthHolland.

Dollar, David. 1992. "Outward-Oriented Developing Economies Really Do Grow More Rapidly: Evidence from 95 LDCs, 1976-1985." Economic Development and Cultural Change 40(3): 523-44.

Easterly, William. 1995. "Explaining Miracles: Growth Regressions Meet the Gang of Four." In Growth Theories in Light of the East Asian Experience, edited by Takatoshi Ito and Anne O. Krueger. Chicago: University of Chicago Press.

Easterly, William, and others. 1993. "Good Policy or Good Luck? Country Growth Performance and Temporary Shocks." Journal of Monetary Economics 32(3): 459-83.

Elias, Victor J. 1992. Sources of Growth: A Study of Seven Latin American Economies. San Francisco: Institute for Contemporary Studies Press.

Englander, A. Steven, and Andrew Gurney. 1994. "OECD Productivity Growth: Medium-Term Trends." OECD Economic Studies 22: 111-29.

Fagerberg, Jan. 1994. "Technology and International Differences in Growth Rates." Journal of Economic Literature 32(3): 1147-75.

Fischer, Stanley. 1993. "The Role of Macroeconomic Factors in Growth." Journal of Monetary Economics 32(3): 485-512. 
Fishlow, Albert, and others. 1994. Miracle or Design? Lessons from the East Asian Experience. Washington: Overseas Development Council.

Grossman, Gene M., and Elhanan Helpman. 1991. Innovation and Growth in the Global Economy. Cambridge, Mass.: MIT Press.

. 1994. "Endogenous Innovation in the Theory of Growth.' Journal of Economic Perspectives 8(1): 23-44.

Harrison, Ann. 1996. "Openness and Growth: A Time-Series, Cross-Country Analysis for Developing Countries." Journal of Development Economics 48(2): 419-47.

Hofman, André. 1993. "Economic Development in Latin America in the 20th Century: A Comparative Perspective." In Explaining Economic Growth: Essays in Honour of Angus Maddison, edited by Adam Szirmai, Burt van Ark, and Dirk Pilat. New York: North-Holland.

Ito, Takatoshi. 1992. The Japanese Economy. Cambridge, Mass.: MIT Press. 1994. "Comment.", In NBER Macroeconomics Annual 1994, edited by Stanley Fischer and Julio J. Rotemberg. Cambridge, Mass.: MIT Press.

Ito, Takatoshi, and Anne O. Krueger. 1995. Growth Theories in Light of the East Asian Experience. Chicago: University of Chicago Press and National Bureau of Economic Research.

Jefferson, Gary H., Thomas G. Rawski, and Yuxin Zheng. 1995. "Chinese Industrial Productivity: Trends, Measurement Issues, and Recent Developments.' Unpublished paper. University of Pittsburgh, Department of Economics (September).

Jorgenson, Dale W., Frank M. Gollop, and Barbara M. Fraumeni. 1987. Productivity and U.S. Economic Growth. Cambridge, Mass.: Harvard University Press.

Judson, Ruth. 1996. “Measuring Human Capital Like Physical Capital: What Does It Tell Us?' Unpublished paper. Board of Governors of the Federal Reserve System (May).

Kim, Jong-Il, and Lawrence J. Lau. 1994. “The Sources of Economic Growth of the East Asian Newly Industrialized Countries.' Journal of the Japanese and International Economies 8(3): 235-71.

King, Robert G., and Ross Levine. 1994. "Capital Fundamentalism, Economic Development, and Economic Growth.' Carnegie-Rochester Conference Series on Public Policy 40: 259-92.

Knack, Stephen, and Philip Keefer. 1995. “Institutions and Economic Performance: Cross-Country Tests Using Alternative Institutional Measures.", Economics and Politics 7(3): 207-27.

Krueger, Anne O. 1995. "East Asian Experience and Endogenous Growth Theory." In Growth Theories in Light of the East Asian Experience, edited by Takatoshi Ito and Anne O. Krueger. Chicago: University of Chicago Press and National Bureau of Economic Research. 
Krugman, Paul. 1992. "Toward a Counter-Counterrevolution in Development Theory." In Proceedings of the World Bank Annual Conference on Development Economics, edited by Lawrence H. Summers and Shekhar Shah. Washington: World Bank.

- 1994. "The Myth of Asia's Miracle." Foreign Affairs 73(6): 62-78.

Kwon, Jene. 1994. "The East Asia Challenge to Neoclassical Orthodoxy." World Development 22(4): 635-44.

Levine, Ross, and David Renelt. 1992. "A Sensitivity Analysis of CrossCountry Growth Regressions." American Economic Review 82(4): 942-63.

Lucas, Robert E., Jr. 1988. "On the Mechanics of Economic Development." Journal of Monetary Economics 22(1): 3-42.

Maddison, Angus. 1987. "Growth and Slowdown in Advanced Capitalist Economies: Techniques of Quantitative Assessment.' Journal of Economic Literature 25(2): 649-98.

Mankiw, N. Gregory. 1995. "The Growth of Nations." BPEA, 1:1995, 275310.

Mankiw, N. Gregory, David Romer, and David N. Weil. 1992. "A Contribution to the Empirics of Growth." Quarterly Journal of Economics 107(2): 407-37.

Nehru, Vikram, and Ashok Dhareshwar. 1993. "A New Database on Physical Capital Stock: Sources, Methodology and Results." Revista de Análisísis Económico 8(1): 37-59.

1994. "New Estimates of Total Factor Productivity Growth for Developing and Industrial Countries." Policy Research Working Paper 1313. Washington: World Bank.

Nehru, Vikram, Eric Swanson, and Ashutosh Dubey. 1995. “A New Database on Human Capital Stock in Developing and Industrial Countries: Sources, Methodology, and Results." Journal of Development Economics 46(2): 379-401.

Nelson, Richard, and Howard Pack. 1995. "The Asian Growth Miracle and Modern Growth Theory." Unpublished paper. Columbia University and University of Pennsylvania (September).

Pack, Howard. 1992. "Technology Gaps between Industrial and Developing Countries: Are There Dividends for Latecomers?' In Proceedings of the World Bank Annual Conference on Development Economics, edited by Lawrence H. Summers and Shekhar Shah. Washington: World Bank.

- 1994. "Endogenous Growth Theory: Intellectual Appeal and Empirical Shortcomings." Journal of Economic Perspectives 8(1): 55-72.

Page, John. 1994. "The East Asian Miracle: Four Lessons for Development Policy." In NBER Macroeconomics Annual 1994, edited by Stanley Fischer and Julio J. Rotemberg. Cambridge, Mass.: MIT Press. 
Pritchett, Lant. 1995. “Where Has All the Education Gone?', Unpublished paper. World Bank (June).

Psacharopoulos, George. 1994. "Returns to Investment in Education: A Global Update." World Development 22(9): 1325-43.

Rodrick, Dani. 1994. "Getting Interventions Right: How South Korea and Taiwan Grew Rich.', Working Paper 4964. Cambridge, Mass.: National Bureau of Economic Research (December).

1995. "Trade Strategy, Investment and Exports: Another Look at East Asia.,' Working Paper 5339. Cambridge, Mass.: National Bureau of Economic Research (November).

Romer, Paul M. 1986. "'Increasing Returns and Long-Run Growth.' Journal of Political Economy 94(5): 1002-37.

1990. “Endogenous Technical Change." Journal of Political Economy 98(5, part 2): S71-S102.

-. 1993. "Idea Gaps and Object Gaps in Economic Development.", Journal of Monetary Economics 32(3): 543-73.

- 1994. “The Origins of Endogenous Growth.' Journal of Economic Perspectives 8(1): 3-22.

Rostow, Walter W. 1960. The Stages of Economic Growth: A Non-Communist Manifesto. Cambridge: Cambridge University Press.

Sachs, Jeffrey D., and Andrew Warner. 1995. "Economic Reform and the Process of Global Integration.” BPEA, 1:1995, 1-95.

Singh, Ajit. 1994. "Openness and the Market Friendly Approach to Development: Learning the Right Lessons from Development Experience.' World Development 22(12): 1811-23.

1996. "Savings, Investment and the Corporation in the East Asian Miracle.' Unpublished paper. United Nations Conference on Trade and Development (March).

$\rightarrow$ Stiglitz, Joseph E. 1996. “Some Lessons from the East Asian Miracle.'” World Bank Research Observer 11(2): 151-77.

Summers, Robert, and Alan Heston. 1991. "The Penn World Table (Mark 5): An Expanded Set of International Comparisons, 1950-1988.' Quarterly Journal of Economics 106(2): 327-68.

United Nations Conference on Trade and Development. 1987. Handbook of Trade Control Measures of Developing Countries 1987. New York: United Nations.

Wade, Robert. 1990. Governing the Market: Economic Theory and the Role of Government in East Asian Industrialization. Princeton, N.J.: Princeton University Press.

World Bank. 1987. World Development Report. New York: Oxford University Press. 
1993a. The East Asian Miracle: Economic Growth and Public Policy. New York: Oxford University Press.

. 1993b. Sustaining Rapid Development in East Asia and the Pacific. Washington: World Bank.

Young, Alwyn. 1991. "Learning by Doing and the Dynamic Effects of International Trade." Quarterly Journal of Economics 106(2): 369-405. . 1994. "Lessons from the East Asian NICs: A Contrarian View." European Economic Review 38(3-4): 964-73.

- 1995. "The Tyranny of Numbers: Confronting the Statistical Realities of the East Asian Growth Experience." Quarterly Journal of Economics 110(3): 641-80. 